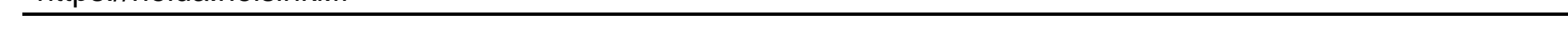




\section{Global philanthropy: Does institutional context matter for}

\section{charitable giving?}

Published as:

Wiepking, Pamala, Femida Handy, Sohyun Park, Michaela Neumayr, René Bekkers, Beth Breeze, Arjen de Wit, Chris Einolf, Zbignev Gricevic, Wendy Scaife, Steffen Bethmann, Oonagh B. Breen, Chulhee Kang, Hagai Katz, Irina Krasnopolskaya, Michael D. Layton, Irina Mersiyanova, KuangTa Lo, Una Osili, Anne Birgitta Pessi, Karl-Henrik Sivesind, Naoto Yamauchi, Yongzheng Yang. (2021). Global Philanthropy: Does Institutional Context Matter for Charitable Giving?. Nonprofit and Voluntary Sector Quarterly, https://journals.sagepub.com/doi/pdf/10.1177/0899764021989444.

\section{Authors}

Pamala Wiepking

Visiting Stead Family Chair in International Philanthropy and Visiting Associate Professor of

Philanthropic Studies.

Lilly Family School of Philanthropy

Indiana University Purdue University

310 University Boulevard

University Hall, Suite 3000

Indianapolis, IN 46202, USA

Email:pwiepki@iu.edu

Tel: +1 (317) 278-8965

Professor of Societal Significance of Charitable Lotteries

Center for Philanthropic Studies

Vrije Universiteit Amsterdam

De Boelelaan 1081

1081 HV Amsterdam, the Netherlands

+31(0)205986782

p.wiepking@vu.nl 
Femida Handy (corresponding author)

School of Social Policy \& Practice

University of Pennsylvania

Philadelphia, United States of America

Email: fhandy@sp2.upenn.edu

Tel: + 1 (215) 573-2660

Fax: 215/573-2099

Sohyun Park

The Center for Social Welfare Research

Yonsei University

Seoul, Republic of Korea

Email: sagua1216@gmail.com

Michaela Neumayr

Institute for Nonprofit Management

WU Vienna

Vienna, Austria

Email: michaela.neumayr@wu.ac.at

René Bekkers

Center for Philanthropic Studies

Vrije Universiteit Amsterdam

Amsterdam, the Netherlands

Email: R.Bekkers@vu.nl 
Beth Breeze

Centre for Philanthropy

School of Sociology, Social Policy and Social Research

University of Kent

Canterbury, United Kingdom

Email: b.breeze@kent.ac.uk

Arjen de Wit

Center for Philanthropic Studies

Vrije Universiteit Amsterdam

Amsterdam, Netherlands

Email: a.de.wit@vu.nl

Chris Einolf

Department of Sociology

Northern Illinois University

DeKalb, United States of America

Email: ceinolf@niu.edu

Zbignev Gricevic

Berlin Graduate School of Social Sciences (BGSS)

Department of Social Sciences

Humboldt-Universität /

DIW Berlin 
Berlin, Germany

Email: ZGricevic@diw.de

Wendy Scaife

The Australian Centre for Philanthropy and Nonprofit Studies

QUT Business School

Brisbane, Australia

Email: w.scaife@qut.edu.au

Steffen Bethmann

Center for Philanthropy Studies

Universität Basel

Basel, Switzerland

Email: steffen.bethmann@unibas.ch

Oonagh B. Breen

Sutherland School of Law

University College Dublin

Dublin, Ireland

Email: oonagh.breen@ucd.ie

Chulhee Kang

School of Social Welfare

Yonsei University

Seoul, Republic of Korea

Email: chulheekang@yonsei.ac.kr 


\section{Hagai Katz}

Guilford Glazer Faculty of Business and Management

Ben-Gurion University of the Negev

Beer-Sheva, Israel

Email: KatzH@som.bgu.ac.il

Irina Krasnopolskaya

The Centre for Civic Initiatives Assessment

National Research University Higher School of Economics

Moscow, Russia

Email: ikrasnopolskaya@hse.ru

Michael D. Layton

Dorothy A. Johnson Center for Philanthropy

Grand Valley State University

Grand Rapids, United States of America

Email: laytonm@gvsu.edu

Irina Mersianova

Centre for Studies of Civil Society and the Non-Profit Sector

National Research University Higher School of Economics

Moscow, Russia

Email: imersianova@hse.ru 
Kuang-Ta Lo

Department of Public Finance

National Chengchi University

Taipei, Taiwan

Email: vancelo@nccu.edu.tw

Una Osili

Lilly Family School of Philanthropy

Indiana University Purdue University

Indianapolis, United States of America

Email: uosili@iupui.edu

Anne Birgitta Pessi

Department of Practical Theology

University of Helsinki

Helsinki, Finland

Email: anne.b.pessi@helsinki.fi

Karl Henrik Sivesind

Institutt for Samfunnsforskning

Oslo, Norway

Email: k.h.sivesind@ samfunnsforskning.no 
Naoto Yamauchi

Osaka School of International Public Policy

Osaka University

Osaka, Japan

Email: yamauchi@osipp.osaka-u.ac.jp

Yongzheng Yang

Lilly Family School of Philanthropy

Indiana University Purdue University

Indianapolis, United States of America

Email: yangyon@iu.edu

\section{Author contributions}

P.W. and F.H. designed research; P.W., F.H., S.P., M.N., R.B., B.B., C.E., Z.G., W.S., S.B., O.B., C.K., H.K., I.K., M.L, I.M., K.L., U.O., A.P, K.S., A.W., and N.Y. contributed to data collection and synchronization; P.W., F.H., S.P., Z.G., Y.Y. analyzed the data; and P.W., F.H., M.N., R.B., B.B., A.W. wrote the paper.

\section{\$XWKRUVף1RWH}

The authors would like to thank the anonymous reviewers and NVSQ editor Angela Bies for their feedback and suggestions which significantly contributed to this article. They would also like to thank all data authorities and data contributors for enabling the creation of the International Individual Philanthropy Database (IIPD 2016), including SOEP, The Beautiful 
Foundation, COPPS-PSID (and especially Mark Ottoni-Wilhelm), CSGVP, IFLS, HBS, ENAFI, GINPS, CNCSNS and TSCS. We would especially like to thank Ge Jiang and Astrid de Jong for support with data management, and Jonathan Bergdoll, Jeroen Weesie and Fengjing Zhang for their feedback on data management and analyses, and Omkar Katta for his editing skills. We further would like to thank all the experts who provided country specific information in the case of missing values in the original sources, including Henriëtta Grönlund, Georg von Schnurbein and Silvia Garcia, and the participants to the 2016 ISTR and 2017 ARNOVA conferences for valuable feedback.

Funding:Pamala Wiepking was funded for her work in this paper by The Netherlands Organisation for Scientific Research grant VI 451-09-022 and by the SPP Do Good Institute - ARNOVA Global Philanthropy \& Nonprofit Leadership Award. Her work at the Lilly Family School of Philanthropy is funded by the Stead Family, her work at the Vrije Universiteit Amsterdam is funded by the Dutch Charity Lotteries. Femida Handy was funded IRUKHUZRUNLQWKLVSDSHUEIWKH8QLYHUVLWIRI3HQQVIOYDQLDIV3850PHQWRUVKLSJ authors are grateful for the support and funding received.

\section{Keywords}

Global philanthropy, institutional contexts, charitable giving, legal, fiscal incentives 


\begin{abstract}
In this paper, we examine whether and how the institutional context matters when XQGHUVWDQGLQJLQGLYLGXDOVIJJLYLQJWRSKLODQWKURSLFRUJDQL]DWLRQV:HSRVLV LQGLYLGXDOVIISURSHQVLWIWRJLYHDQGWKHDPRXQWVJLYHQDUHKLJKHULQFRXQWUL institutional context for philanthropy. We examine key factors of formal and informal institutional contexts for philanthropy at both the organizational and societal levels, including regulatory and legislative frameworks, professional standards, and social practices. Our results show that while aggregate levels of giving are higher in countries with stronger institutionalization, multi-level analyses of 118,788 individuals in 19 countries show limited support for the hypothesized relationships between institutional context and philanthropy. The findings suggest the need for better comparative data to understand the complex and dynamic influences of institutional contexts on charitable giving. This, in turn, would support the development of evidence-based practices and policies in the field of global philanthropy.
\end{abstract}




\section{Introduction}

There is abundant research showing how individual motivations and resources influence giving to philanthropic organizations ${ }^{1}$ (Bekkers \& Wiepking, 2011b; Wiepking \& Bekkers, 2012). Less is known about how the context in which people live influences this behavior (Barman, 2017). This is surprising as LWLV $\ddagger F H U W D L Q W K D W S K L O D Q W K U R S Z Z R X O G Q R W K D Y H$ it currently does in the absence of the various laws that structure it. (Reich, 2006, p. 17). Analogous research on the institutional context for blood and organ donations finds that collection regimes of countries strongly influence individual donation behavior (Healy, 2006; Johnson \& Goldstein, 2003), suggesting that philanthropic donations may be influenced by the institutional contexts (Barman, 2007; Galaskiewicz \& Burt, 1991; Galaskiewicz \& Wasserman, 1989; Mosley \& Galaskiewicz, 2010; Sargeant, 1999; Schervish \& Havens, 1997).

In this paper, we contribute to the global philanthropy literature by examining how individual charitable giving is associated with the institutional philanthropic context of a country. Specifically, we examine key factors of the formal and informal institutional context for philanthropy at both the organizational and the societal levels, including regulatory and legislative frameworks, professional standards, and social practices. Analyzing how institutional contexts relates to individual charitable giving is instrumental for understanding how societies can be shaped to contribute, through philanthropy, to benefit others and the public good. We test our hypotheses by analyzing merged and synchronized datasets from 19 countries: The International Individual Philanthropy Database (IIPD). The IIPD uniquely includes both incidence and amounts of individual donations as well as relevant individuallevel characteristics. 
To our knowledge, this is the first paper to empirically examine how the institutional context for philanthropy relates to the individual incidence and level of giving across a range of countries. Lacking individual-level data on the amount of philanthropic donations, past studies typically used aggregated measures or analyzed data with bivariate correlational analyses (CAF, 2017; Einolf, 2016; Sokolowski, 2013). While these studies contributed to an initial understanding of global philanthropy, we show that these studies may have overestimated support for relationships between institutional contexts and philanthropy.

We also show the importance of considering the demographic characteristics of countries when studying the relationship between institutional context for philanthropy and individual giving. We find that if people in countries with less developed philanthropic institutional context (typically developing economies) had the same average age, level of education and income as those in countries with more developed philanthropic institutional contexts, they would be equally likely to give and to give similar amounts. This points to a higher relative importance of individual level resources for charitable giving, rather than the philanthropic infrastructure, at least in relation to the factors of institutionalization included in our study.

Finally, such comparative analysis is critical for the design of evidence-based policies that relate institutions to the practice of philanthropy. Our findings represent a first attempt at understanding what factors are associated with the differences in individual philanthropic giving across 19 countries, and aim to contribute to a new research agenda focused on understanding global differences in philanthropic behavior. 


\section{Theory and hypotheses}

There are large differences in individual giving to philanthropic organizations in different countries (Wiepking \& Handy, 2015; Wiepking \& Handy, 2016b). Figure 1 shows that the average annual donation to charity per person ranges from the equivalent of 12 US\$ in Russia to 1,427 US\$ in the United States.

[Figure 1 here]

What contextual underpinnings can explain these large differences in individual giving across countries? In a qualitative content analysis of 136 contextual factors identified by experts from 26 countries and regions to facilitate or inhibit philanthropy, Wiepking and Handy (2015) identified several key factors. These relate to the institutional context for philanthropy at both the organizational and the societal level, including regulatory and legislative frameworks, professional standards, and social practices.

Our main hypothesis is that the stronger the institutional context for philanthropy is in a country, the more likely people are to give and to give higher amounts to philanthropic organizations. We use the notion of institutionalization of philanthropyII to refer to the socially constructed system of norms, beliefs and definitions manifested in different institutions that shapes DQLQGLYLGPH)Qff(thropic behavior by providing legitimacy (Scott, 2008) and influences transaction costs for that behavior (North, 1990). We define institutions as łaspects of societal structure or human-devised rules of the game of society which give VROLGLWIII>WRVRFLDOVIVWHPV@ DFURV (CWddRhH,QWW,SDEH). In doing so, institutions consist of both formal rules (e.g., laws backed by authorized powers) and informal ones (e.g., customs or traditions deriving from a set of shared norms), which guide 
and constrain individual behavior (Scott, 2008).

Formal institutionalization includes the legal framework in a country: laws, contracts and judicial rules. In a complex society, such rules govern interactions and transactions. Within this class of institutionalization, Ingram and Clay (2000) distinguish public rules made by governmental authorities from private rules made by private organizations. Informal institutionalization, instead, refers to informal norms as constraints that define our set of choices in daily life (North, 1990). Together, public and private institutions that are formal as well as informal provide the context in which individuals make gifts to charitable organizations.

As we elaborate below, the role of institutions, and regulations more generally, can reduce transaction costs for donors WKH†VXSSONGH·DQGWKositively influence giving. At the same time, such regulations may increase transaction costs for organizations WKH‡GHPDQG VLGH and thus could also negatively influence giving, especially for smaller organizations and especially in the short-run as they must adopt regulations regarding reporting, transparency and fundraising. However, over time, as organizations learn and adapt, and become more effective and undertake varied best practices for fundraising, regulations may positively influence giving on the demand side as well. Indeed, research at the level of individual donors has shown that lowering costs of giving and providing more opportunities to give increases philanthropy (Bekkers \& Wiepking, 2011a). 


\section{Regulations and Fiscal Incentives: Formal-public institutionalization}

Regulations that curb the power of philanthropic organizations to commit fraud ensures that only legitimate and trustworthy organizations solicit donations. On the one hand, this enables individuals to donate while reducing their transaction costs related to monitoring the quality of organizations (Hogg, 2017). On the other hand, these and other regulations can increase costs for the establishment and operation of philanthropic organizations, reducing giving (Huck \& Rasul, 2010; Knowles \& Servátka, 2015). The regulations may increase barriers to entry, and consequently decreases the number of philanthropic organizations and thus provide fewer opportunities for charitable donations, consequently reducing overall philanthropy, especially in the short term. On balance, while government regulation, such as compulsory registration for organizations involved in fundraising, provides legitimacy to the philanthropic sector and lowers transaction costs for individual donors, if too cumbersome for organizations it can also reduce giving.

Regulations, posited by North (1992), are driven by the need to create efficiency and resolve issues and arising from: (1) information and measurement costs (Can the donor be sure the donation will buy the desired service and in the right quantity?); (2) the costliness of the exchange and size of the market (How can donors buying service for an unknown third party ensure it was done as contracted? How to protect the rights of the donor?); (3) enforcement (Who will enforce the rights of the donor?). However, while regulations are designed to efficiently resolve these above-mentioned issues, they are in fact, heavily influenced by political actors and prevailing ideology (North, 1992). Such influence can raise or lower transaction costs for organizations and individuals, change the perception of fairness of the regulations and thereby impact the overall sector, in ways that may or may not promote 
efficiency, illustrated by the case of nonprofit reforms in China described by $\mathrm{Hu} \& \mathrm{Guo}$ (2016).

Overall, government regulation is a complex phenomenon varying greatly across countries (Breen, Dunn, \& Sidel, 2016). Nevertheless, it does contribute to more efficient philanthropic organizations, making them attractive to donors (Breen, Dunn, \& Sidel, 2016; Cagney \& Ross, 2013; Marx, 2015). However, if regulations increase transaction costs for nonprofits, if they are opaque or difficult to follow or if they are perceived as unfair or undemocratic, they may have negative effects on their growth as well raise barriers to entry and limit the philanthropic sector (EU Russia Civil Society Forum, 2017; Vandor, Traxler, Millner, \& Meyer, 2017; Wiepking \& Handy, 2015). Due to the complexity of government regulations, here we focus only on registration for philanthropic organizations, which is easily comparable between countries. We hypothesize:

H1: The ease and fairness in government registration for philanthropic organizations is positively related to the individual level of philanthropic giving to charitable organizations in a country.

Government regulations that offer fiscal incentives for philanthropic donations also suggest that donating is a legitimate, socially desired behavior that is publicly sanctioned. Furthermore, fiscal incentives also reduce WKHSULFH\&BSTations to the donor, thereby increasing philanthropic activity (Bakija \& Heim, 2011; Duquette, 2016; Kingma, 1989). We hypothesize: 
H2: The level of fiscal incentives for philanthropic donations is positively related to the individual level of philanthropic giving to charitable organizations in a country.

\section{Education and Training: Formal-private institutionalization}

Philanthropic practices are influenced by formal rules made by private institutions. For example, giving may be facilitated by nonprofit education programs and fundraising professionalization. Nonprofit education programs are a private form of institutionalization that legitimizes philanthropy. ${ }^{3}$ For example, as the philanthropic sector grows and its activities get more specialized, there is a need for personnel that are specially trained to manage philanthropic organizations and engage in fundraising (Mirabella, Gemelli, Malcolm, \& Berger, 2007; Mirabella \& Wish, 2001). Thus, the degrees in higher education related to management of nonprofits are an indicator of the professionalization of philanthropy. As trained personnel typically enhances the benefits and impact of donations made to nonprofits, donors are more satisfied and likely to give more (Bekkers \& Wiepking, 2011a). We hypothesize:

H3: The number of nonprofit education programs is positively related to the individual level of philanthropic giving to charitable organizations in a country.

A related form of professionalization influencing giving is the training of those soliciting donations. Empirical findings show that solicitation is a critical motivator of giving; the majority of donations are prompted by a request (Bekkers \& Wiepking, 2011a; Breeze, 2017; Neumayr \& Handy, 2019, Yörük, 2009). Not surprisingly, if individuals are not asked to donate, individuals are unlikely to give. Fundraising, done well, can increase donations by reducing donors IWUDQVDFWLRQWRAVSWI awareness for the need for donations 
(Schlegelmilch, Love, \& Diamantopoulos, 1997; Wiepking \& Maas, 2009; Yörük, 2009). When donors are treated well by fundraisers, donors are more satisfied and likely to give more (Breeze, 2017). According to Breeze and Scaife (2015), well trained fundraisers follow relationship-centric and not transactional fundraising approaches, conduct many different types of appeals and are supported by institutions that regulate and promote best practices, all of which promotes successful solicitations. Thus, we expect that a higher degree of development of the fundraising professionals will facilitate fundraising, and hence is associated with greater level of giving. We hypothesize:

H4: Development of the fundraising profession is positively related to the individual level of philanthropic giving to charitable organizations in a country.

\section{Norms: Informal institutionalization}

Informal institutionalization usually refers to group norms, i.e., cognitive schemata that are commonly recognized and culturally supported such as customs, taboos or traditions (Ingram \& Clay, 2000; Mair \& Hehenberger, 2014; North, 1990; Scott, 2008). Such informal norms are both constraints that may limit and sanction transactions (North, 1990) and cultural lenses that give meaning to social phenomena (Scott, 2008). Although government legislation is part of the formal-public institutionalization, we suggest that government funding of nonprofits is the reflection of a group norm. Government grants are used to signal the legitimacy of the nonprofit sector (Handy, 2000; Heutel, 2014) and also signal desired social behavior as government expenditures are the reflection of democratic processes and shared values (Saunders-Hastings, 2018). 
Government funding could be \$FURZG̈g-RXW-SKLODQWKURSLFEmnEterfer \& Neumayr, 2017; Sokolowski, 2013; Bekkers \& De Wit, 2013; De Wit, Neumayr, Handy, \& Wiepking, 2018). This is supported by evidence in laboratory experiments, but studies that use field data generally find little evidence (Bekkers \& De Wit, 2013; Lu, 2016). In the practice of philanthropy, it is more likely that decisions are guided by shared beliefs about what are goodII philanthropic causes, which may UHVXOWLQ\$FURZGMRJargue that government funding reflects such shared beliefs. We hypothesize that, in general, the larger the share of the funding received from the government by nonprofits, the more their activities are perceived as relevant and necessary, which in turn increases individualsđ giving.

H5: A higher share of government funding for philanthropic organizations is positively related to the individual level of philanthropic giving to charitable organizations in a country.

A final form of informal institutionalization of philanthropy relates to the social norms that encourage philanthropy. When social norms are more supportive of giving, it will positively influence individual giving (Ariely, Bracha, \& Meier, 2009; Simpson \& Willer, 2015). For example, religious norms for giving are especially strong, and exist across almost all religions, inspiring charity in their adherents (Bekkers \& Schuyt, 2008; Bennett \& Einolf, 2017; Wuthnow, 1991). We hypothesize:

H6: The proportion of people in a country that is religiously affiliated is positively related to the individual level of philanthropic giving to charitable organizations in a country. 
In formulating these hypotheses, we are cautious in suggesting that there exists a unidirectionality in these relationships; just as LQVWLWXWLRQVVKDSHLQGLYL6Xdod| IEHKDYLRU individuals shape institutions. For example, it may well be that an easy and fair nonprofit registration system will emerge only when there a sufficient level of philanthropic activity, as very low philanthropic activity may not trigger a need for a bureaucratic registration process. However, after a certain threshold of philanthropic activity, governments may decide that registration of nonprofits would reduce fraudulent behaviors as well as information and monitoring costs to donors. Registration reduces transaction costs to donors, and this in itself may spur increased philanthropic activity. Similarly, it can be argued that when philanthropic activity is high, nonprofits can lobby for fiscal incentives (DOWKRXJKWKHJRYHUQPHQWVII resistance may also be high if the cost to the treasury is perceived sufficiently large). Given that the only data currently available to test our hypotheses is cross-sectional, such directionality or causality cannot be determined, and thus our findings needed to be interpreted with caution. ${ }^{4}$

\section{Data and measures}

Research documents the ubiquitous presence of philanthropy across the world, but most studies thus far have concentrated on single countries or regions, especially in Western Europe and North America, and typically analyze only aggregated country-level data about individual philanthropic behavior (e.g., Bekkers, Schuyt, \& Gouwenberg, 2017; ESS, 2002; Papacostas, 2008; Giving USA, 2016; Hoolwerf \& Schuyt, 2017; Philanthropy Age, 2016). One exception is the Gallup World Poll, but these data are not publicly available and only provide the incidence of giving, and not amounts donated (Gallup, 2018), which we argue is 
key in understanding the relationship between institutional contexts and individual donating (Wiepking \& Handy, 2015a).

A new and unique database, created by Wiepking and Handy (2016b), merged and synchronized micro-level datasets from 19 countries: The Individual International Philanthropy Database (IIPD). It includes the incidence and amounts of individual donations as well as relevant individual-level characteristics: gender, age, marital status, income and level of educational achievement. Data were collected using probability-based sampling in Australia (Lyons \& Passey, 2007), Austria (Neumayr \& Schober, 2009), Canada (CSGVP, 2004), France (Wiepking, 2009), the Netherlands (Wiepking, Bekkers, Schuyt, \& Gouwenberg, 2006), the United Kingdom (Low, Butt, Paine, \& Smith, 2007), the United States (Wilhelm, 2005), Norway (Wollebæk \& Sivesind, 2010), Finland (Pessi \& Grönlund, 2008), Mexico (ENAFI, 2005), South Korea (The Beautiful Foundation, 2006), Japan (Japan Fundraising Association, 2010), Indonesia (Strauss, Witoelar, Sikoki, \& Wattie, 2009), Taiwan (TSCS, 2009), Israel (Haski-Leventhal, Katz, \& Yogev-Keren, 2011), Ireland (HBS, 2005), Russia (CSCSNS, 2010), Germany (Schupp, 2009; Wagner et al., 2010), and Switzerland (Stadelmann-Steffen \& Freitag, 2011). The IIPD is a non-overlapping multiple frame sample (Kaminska \& Lynn, 2017).

There exists several methodological weaknesses, i.e., different timeframes, sampling methods (Abraham, Helms, \& Presser, 2009) and questionnaires (Bekkers \& Wiepking, 2006; Rooney, Steinberg, \& Schervish, 2004) were used. These differences may lead to different estimated relationships between factors of institutionalization and philanthropic giving. However, until other micro-level data is collected, the IIPD is the best available data to test relationships between institutional contexts and individual philanthropy across a range of countries. More 
information on datasets is available in Online Appendix A, and in the IIPD documentation (Wiepking \& Handy, 2016a).

In the IIPD, the proportion of the population surveyed differs strongly between countries. Following Kaminska and Lynn (2017) a cross-national weight, reflecting the relative inclusion probability within each country, was created using population scaling:

$$
W_{i j}^{s}=N_{j} / n_{\mathrm{j}}
$$

Where $W^{s}{ }_{i j}$ is the national population weight for the unit $i$ in country $j$;

$N_{j}$ is the sample size in country $j$;

And $n_{\mathrm{j}}$ is the population size $\mathrm{s}^{5}$ of country $j$.

The IIPD consists of 138,927 respondents in 19 countries. The country datasets in the IIPD were collected between 2004 and 2011, depending on the availability of data at the countrylevel. List-wise deletion was used for missing values, resulting in 118,788 respondents from 19 countries.

Table 1 provides describes the measurements used; Table 2 provides an overview of the measures of philanthropy and institutionalization; and Table 3 provides descriptive statistics for measures of institutionalization examined. ${ }^{6}$

[Tables 1, 2 and 3 here] 
Table 4 shows the bivariate correlation between the measures of institutionalization (with continuous measures) and amounts donated (individual and aggregated country level). When it is easier to form, register, operate, and dissolve philanthropic organizations, when there are more nonprofit education programs, and when the proportion of nonprofit revenue from public sources is higher, people give higher amounts. We find no relationship between the proportion of religiously affiliated in a country and levels of giving. Interestingly, the correlation between country-level average donation and the significantly related measures of institutionalization is between 0.25 (nonprofit revenue from public sources) and 0.45 (ease of forming philanthropic organizations) stronger than for individual-level donations, suggesting that cross-national studies using aggregate measures may overestimate relationships. ${ }^{7}$

Table 5 shows the average proportion of donors and average donations for each of the fiscal incentive categories. Dismissing the results for fiscal incentives represented by only one country (categories 4 to 7), people in countries with a combination of an egalitarian and pragmatic fiscal incentive system are most likely to give and give the highest amounts to charitable organizations. While the likelihood of giving is similar for people in a pure egalitarian or pragmatic fiscal regime, people in a pragmatic regime donate on average higher amounts.

The relationship between fundraising regimes and giving in Table 6 , shows that the likelihood of giving does not necessarily increase with advancement of fundraising regimes (i.e., development of the profession, technology, positive public attitudes towards fundraising). People are most likely to give in established fundraising regimes (the fourth category), followed by advanced regimes (only represented by the US), and emerging and 
evident regimes. The relationship between a fundraising regime and donations is as expected; the more advanced a fundraising regime, the higher the average amounts people give.

[Tables 4, 5 and 6 here]

\section{Analytical models}

To understand the relationships between the institutionalization measures and the incidence and level of giving, we tested the relationship using multilevel mixed-effects logistic regression analyses (Table 7) and Maximum Likelihood (ML) mixed-effects multilevel models (Table 8) using Stata 15. In multilevel analyses, the clustering of individuals within countries is considered to avoid the issues arising in previous studies, which used aggregated data in combination with bivariate correlational analyses. We estimated the predicted probability and linear prediction of donating for different institutional measures (Figure 2 and 3 and Tables 9 and 10).

\section{Results}

The relationship between institutional context and the likelihood of giving

Table 7 displays the results from maximum likelihood multilevel mixed-effects regression analyses of the likelihood of giving. ${ }^{8,9}$ The first column shows results from a model including only the individual-level control variables. ${ }^{10}$ In each subsequent model we include one of the contextual measures of institutionalization. Figure 2 displays the predicted probability of donating, estimated using the results from Table 7 . The predicted probability of donating for an individual in a country with various levels of ease of forming philanthropic institutions is calculated based on Model 1 in Table 7, keeping all other covariates at their full sample means. The predicted probabilities in Figure 2 indicates that the relationship between the 
number of nonprofit education programs and the proportion of the population religiously affiliated and the likelihood of giving is positive as expected.

Unexpectedly, the relationships between the ease of forming philanthropic organizations and the proportion of nonprofit revenue from public sources and the likelihood of giving are negative. From Figure 2 and the odds ratios in Table 7, we note that most of the measures of institutionalization are not significantly related with the likelihood of giving, showing little support for the hypotheses. Table 7, however, does show a significant relationship between an established fundraising regime (compared to an evident regime) and the likelihood of making donations. Hence these results only provide support for hypothesis 4 and then only specifically for one type of fundraising regime.

[ Table 7 and Figure 2 here]

The relationship between institutional context and the level of giving

Table 8 displays the results from a maximum likelihood mixed-effects multilevel linear regression analyses of the natural log of the amount donated. ${ }^{11}$ Figure 3 displays the linear prediction of the natural log of the amount donated, estimated using the results from Table 8 .

[ Table 8 and Figure 3 here]

Figure 3 shows that all relationships are as expected: in countries where it is easier to form philanthropic organizations, with more nonprofit education programs, where a higher proportion of the revenues of nonprofits comes from public sources, or where a higher proportion of the population is religiously affiliated, people are predicted to donate, on 
average, higher amounts. However, as can be seen from the coefficient estimates in the models in Table 8, most of our hypotheses were not supported. We do find partial support for hypothesis 2: People in a combination of an egalitarian and pragmatic fiscal system are estimated to donate higher amounts than people in (combinations of) pragmatic, transitional or restrictive systems (Model 2 in Table 8). Hypothesis 4 is also partially supported. People in an established fundraising regime are estimated to give higher amounts than people in an evident fundraising regime (Model 3 in Table 8). To further understand relationships between fiscal incentive systems, fundraising professionalism and incidence and level of giving, we show the predicted probability and the linear prediction of giving for the different categories of fiscal incentive systems (Table 9) and fundraising regimes (Table 10).

[ Tables 9 and 10 here]

Table 9 shows that people in a combination of an egalitarian and pragmatic fiscal system are predicted to donate 102 US\$, compared with 24 US\$ (pure pragmatic system) and 14 US\$ (pure egalitarian system). Canada and France are countries classified by CAF (2016) as egalitarian tax incentive regimes where tax credits have equal benefit for all donors; however the weakness of egalitarian regimes is that the fiscal benefits may be more complex and not easily claimed by donors than those in pragmatic regimes. Pragmatic regimes, such as the United States and Australia, are those where fiscal benefits are relatively easier apply for but those with higher incomes receive higher benefits (CAF, 2016). Our results suggest that a combination of an egalitarian and pragmatic regime may be most beneficial to individual philanthropy, partially supporting hypothesis 2 . However, as our data includes only two countries classified as a combination between egalitarian and pragmatic regime, Switzerland and the United Kingdom, further research is needed to establish this finding. 
People in an established fundraising regime have a predicted probability of donating of 81 percent (Table 10), and are predicted to donate 41 US\$, as compared to 13 US\$ in an evident fundraising regime. This finding partly supports our fourth hypothesis, suggesting that people in established fundraising regimes are more likely to give and give higher amounts.

Comparing results in Table 9 and 10 with the bivariate statistics in Table 5 and 6 illustrates that FRXQWULHVIGHPRJiHflsiknde\/relationships between fiscal incentive systems, type of fundraising regime, and philanthropic giving(VSHFLDOOIWKHELYDULDWHUHVXOWVIRUWKHC institutionalized][FRXQWULHVLQAysteFDand fundraising regime seem to be driven, at least partly, by these countries $\llbracket$ demographics, which are less favorable for donating (e.g., populations are younger, less wealthy and less educated). If people in transitional and restrictive fiscal systems, and embryonic fundraising regimes in particular, had similar levels of income (and to a lesser extent similar ages and education), they may be just as (or even more) generous than people in countries with more advanced types of fiscal systems and fundraising regimes.

We conducted several robustness tests, controlling for per capita Gross National Income (GNI) in the multilevel analyses, estimating the multi-level models using the amounts

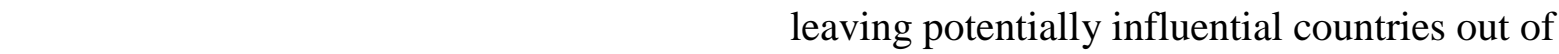
the analyses, and including all measures of institutionalization in one model. The results of these tests do not lead to different findings than reported. A description of these robustness tests and results are available through Online Appendices. 


\section{Conclusion and discussion}

We examined how the institutional context for philanthropy, manifested in different formal and informal institutions, relates to individual philanthropic behavior across a range of 19 countries. We argued that the stronger the institutional context for philanthropy is in a country, the more people are likely to give and to give higher amounts to philanthropic organizations. In other words, the more strongly philanthropy is supported by organizational and societal structures, the more donors will give.

We find that -considering bivariate statistics and simple correlational tests - when there is more ease and fairness in government registration for philanthropic organizations, when the fiscal incentive system for philanthropic giving can be characterized as both egalitarian and pragmatic (e.g., United Kingdom and Switzerland), when there are more formal training opportunities for people working in the philanthropic sector, when fundraising is more developed, when there is proportional more government funding for philanthropic organizations, people are more likely to give, and give higher amounts of money to philanthropic organizations. Thus, at the bivariate level, the institutionalization of philanthropy through formal and informal rules positively relates to more and higher individual giving to philanthropic organizations.

However, these results pertain strictly to bivariate statistics and bivariate correlational tests. When using multilevel analyses, we find less support for our ideas. The results of these more stringent analyses show that only people in an established fundraising regime have a higher probability of donating and give higher amounts compared with people in an evident fundraising regime. In addition, we found that people in a combination of egalitarian and pragmatic fiscal incentive regime are predicted to donate higher amounts than people in 
(combinations) of pragmatic, transitional and restrictive fiscal incentive systems. However, as our data includes only two countries classified as a combination between egalitarian and pragmatic regime, Switzerland and the United Kingdom, further research is needed to establish this finding.

The results are also suggestive of a positive relation between the number of nonprofit education programs and the predicted level of giving in a country ( $p$ :HGRQRWILQG support for any of the other expected relationships. This leads us to the first important message from our study: Past empirical comparative studies of philanthropy, that examined only bivariate correlational relationships using only aggregated measures for individual philanthropic giving, may well have overestimated or over-stated relationships.

Although not hypothesized, a significant finding for the understanding of global philanthropy, is that if people in countries with lower levels of philanthropic institutionalization, typically developing economies, had the same average age and level of education and especially income as those in countries with more advanced levels of philanthropic institutionalization, they would be equally likely to give and give similar amounts. Indeed, a large part of the variation between countries in the individual likelihood of giving and level of giving can be explained by compositional demographic differences between coXQWULHVIISRSXODWLRQV)URPRXUUHVXOWVLWFDQEHH[SHFWHGWKDWZKHQ developing economies start to resemble populations in developed economies more, we expect the likelihood and level of giving in developing economies will go up, independent of the level of philanthropic institutionalization. This is the second key message of our study. 
When interpreting the results, we bear in mind the relatively low number of countries included in our study, and thus the limitations in the generalizability of our findings. Nevertheless, our results are the first of their kind and point to relationships that could spur further research. Although the 19 countries in the IIPD represent twenty-one percent of the ZRUOGIVSRSXODWTiteRIQNations, 2017), there is an overrepresentation of countries situated in Western-Europe, North America and Asia. Furthermore, Elff, Heisig, Schaeffer, and Shikano (2016) suggest that using a REML estimation eliminates the bias in multilevel analyses with a low number of countries. In a robustness test (see Online Appendix C), the REML estimation produced similar results as the multi-level estimation, suggesting that the results are not biased. However, we do expect the results are driven by the selection of countries included in our study. Excluding Germany and Japan, which were the two countries that followed different logics of institutionalization, resulted in somewhat stronger support for our hypotheses (see Online Appendices D1 and D2).

At this time, the IIPD is the only dataset that allows studying how institutional context relates to individual-level philanthropic behavior. Hence, it is not possible to test our data using a larger and less selective range of countries, or data that have been collected using one standardized methodology and survey. We tried to correct the flaws in these data and reported our results conservatively and with caution. Hence, we refrain from policy recommendations based on our results.

Our findings first need to be replicated, in further research using a less selective sample and a higher number of countries, and measurements of philanthropy that capture giving across all countries. To rule out the possibility that our hypotheses were not supported because of measurement problems, future studies should include additional and possibly more direct 
measures. Our findings, we hope will spur scholars and philanthropy professionals to engage in global philanthropy research, contributing to the collection of longitudinal data and comparative analyses. With new data, longitudinal analyses become a possibility, which can address some of the problems with causal inference inherent in cross-sectional designs. While formal and informal institutionalization of philanthropy is continuously being shaped, there is a need for evidence-based policies. Through this, future global philanthropy research can contribute to an understanding of how philanthropy can be a source of societal wellbeing for everyone, and not just for selected populations and groups. 


\section{Endnotes}

${ }^{1}$ Philanthropic organizations are also known as nonprofit organizations or not-for-profit RUJDQL]DWLRQVEXWZHZLOOXVHWKHWHUP $\$$ SKLODQWKURSLFRUJDQL]DWLRQV·FRQVL

these organizations throughout this article. The definition for philanthropic organizations varies across countries, but according to Salamon and Anheier (1992), the common characteristics are that they are private (non-governmental), self-governing organizations, which on a voluntary basis distribute goods and services to benefit a public purpose, without the primary goal of making profits for their owners.

${ }^{2}$ We thank our anonymous reviewer for this insight.

${ }^{3}$ We acknowledge that depending on the country, education programs for philanthropy professionals could also be part of formal-public institutionalization.

${ }^{4}$ In a previous version of this paper, we examined the proportion of volunteers in a country as a correlate of amounts donated. We did not find a relationship between proportion volunteers in a country and incidence and amounts donated.

${ }^{5}$ We used population size in 2003 , the year preceding all measures of giving in the IIPD (United Nations, 2017).

${ }^{6}$ The correlations between measures of institutionalization is displayed in Online Appendix B. Except for the proportion of nonprofit revenue from public sources and the fiscal incentive systems, we included measures of institutionalization that were captured by one source to increase reliability of these measures: ease of forming philanthropic organizations (Adelman, Barnett, \& Russell, 2015); number of nonprofit education programs (Mirabella et al., 2007; Mirabella \& Wish, 2001); type of fundraising regimes (Breeze \& Scaife, 2015); proportion religiously affiliated (Pew Research Center, 2012). For the proportion of nonprofit revenue from public sources, we supplemented the primary data source (Salamon, Sokolowski, \& Haddock, 2017) with data from the Palgrave Handbook on Global Philanthropy (Wiepking \& 
Handy, 2015a). For the fiscal incentive systems, the primary data source (CAF, 2016) was supplemented by country experts (Table 1).

${ }^{7}$ This phenomenon, where an association at the population level may be much weaker or even reversed within subgroups of that population, is documented in the ecological fallacy literature (Kievit et al. 2013; Robinson 2009; Te Grotenhuis, Eisinga, \& Subramanian 2011). ${ }^{8}$ Ideally, we would include the six measures of institutionalization in one model in the multilevel analyses. However, with only 19 countries in the study, six contextual level variables may produce biased results. As a robustness test, we did include all measures of institutionalization in one model; see Online Appendix F for the results. We also created a composite measure for the overall level of philanthropic institutionalization in a country, using Factor Analysis on the six contextual level variables measuring institutionalization. From the factor analysis using oblimin rotation we retained one factor with an eigenvalue over 1 . We included the factor scores in the maximum likelihood mixed-effects multilevel logistic and linear regression, where it functioned as a composite measurement of all institutionalization measurements. The results showed no relationships between this composite measure and likelihood of giving and amounts donated.

${ }^{9}$ Results are calculated using xtmelogit in Stata 15.

${ }^{10}$ The intraclass correlation (ICC) for the model including only individual control variables is 0.251 , indicating that 25 percent of the variance in the likelihood of giving can be explained by the context in which individuals live. We expect that the ICC also captures a design effect, as there are differences in survey design between countries. The ICC likely captures both the WUXHIFRQWH[WXDOYDULDQFHLQWKHOLNHOLKRRGRIJLYLQJDVZHOODVYDULDQFHFD survey designs. The ICC of the different models finds the contextual level variance remains unexplained by our institutionalization measures. The likelihood ratio test (LR test) to test the goodness-of-fit of the models including contextual institutionalization measures finds only 
the model including the proportion of nonprofit revenue from public sources (Model 5) is significantly a better fit for the data compared with the corresponding model only including individual-level control variables $(p$

${ }^{11}$ Results are calculated using xtmixed in Stata 15. The first column in Table 8 shows the results from a model including the individual level control variables. The ICCs of the different models in Table 8 show that only models including fiscal incentive systems (Model 2, Table 8), fundraising regimes (Model 3, Table 8) and number of nonprofit education programs (Model 4, Table 8) explain a little of the contextual level variance in amounts donated, respectively 4.9 percent, 3.9 percent and 1.7 percent. LR tests show that the model including the proportion nonprofit revenue from public sources (Model 5) fits the data significantly better than the corresponding model with individual level control variables only $(p$ 


\section{References}

Abraham, K. G., Helms, S., \& Presser, S. (2009). How Social Processes Distort Measurement: The Impact of Survey Nonresponse on Estimates of Volunteer Work in the United States. American Journal of Sociology, 114(4), 1129-1165.

Adelman, C., Barnett, J. N., \& Russell, K. (2015). Index of Philanthropic Freedom 2015. Washington, DC: Hudson Institute.

Ariely, D., Bracha, A., \& Meier, S. (2009). Doing Good or Doing Well? Image Motivation and Monetary Incentives in Behaving Prosocially. American Economic Review, 99(1), $544-555$.

Bakija, J., \& Heim, B. T. (2011). How Does Charitable Giving Respond to Incentives and Income? New Estimates from Panel Data. In Economic Analysis of Tax Expenditures. National Tax Journal, (National Tax Association), Vol. 64, no. 2, part 2.

Barman, E. (2007). An Institutional Approach to Donor Control: From Dyadic Ties to a Field-Level Analysis. American Journal of Sociology, 112(5), 1416-1457.

Barman, E. (2017). The Social Bases of Philanthropy. Annual Review of Sociology, 43, 271290.

Bekkers, R. H. F. P., \& Schuyt, T. N. M. (2008). And Who Is Your Neighbor? Explaining the Effect of Religion on Charitable Giving and Volunteering in the Netherlands. Review of Religious Research, 50(1), 74-96.

Bekkers, R. H. F. P., Schuyt, T. N. M., \& Gouwenberg, B. M. (Eds.). (2017). Geven in Nederland [Giving in the Netherlands]. Amsterdam: Lenthe Publishers. 
Bekkers, R. H. F. P., \& Wiepking, P. (2006). To Give or Not to Give, That Is the Question: How Methodology Is Destiny in Dutch Giving Data. Nonprofit and Voluntary Sector Quarterly, 35(3), 533-540.

Bekkers, R. H. F. P., \& Wiepking, P. (2011a). A Literature Review of Empirical Studies of Philanthropy: Eight Mechanisms That Drive Charitable Giving. Nonprofit and Voluntary Sector Quarterly, 40(5), 924-973.

Bekkers, R. H. F. P., \& Wiepking, P. (2011b). Who Gives? A Literature Review of Predictors of Charitable Giving Part One: Religion, Education, Age and Socialisation. Voluntary Sector Review, 2(3), 337-365.

Bennett, M. R., \& Einolf, C. J. (2017). Religion, Altruism, and Helping Strangers: A Multilevel Analysis of 126 Countries. Journal for the Scientific Study of Religion, $56(2), 323-341$.

Breen, O. B., Dunn, A., \& Sidel, M. (Eds.). (2016). Regulatory Waves. Comparative Perspectives on State Regulation and Self Regulation Policies in the Nonprofit Sector. Cambridge, UK: Cambridge University Press.

Breeze, B. (2017). The New Fundraisers: Who Organises Charitable Giving in Contemporary Society? Bristol, UK: Policy Press.

Breeze, B., \& Scaife, W. (2015). Encouraging generosity: The Practice and Organization of Fund-raising across Nations. In P. Wiepking \& F. Handy (Eds.), The Palgrave Handbook of Global Philanthropy (pp. 570-596). London, UK: Palgrave Macmillan .

CAF. (2016). Donation States. An International Comparison of the Tax Treatment of Donations. London, UK: Charities Aid Foundation. 
CAF. (2017). World Giving Index 2017. A Global View of Giving Trends. London, UK: Charities Aid Foundation.

Cagney, P., \& Ross, B. (2013). Global Fundraising: How the World Is Changing the Rules of Philanthropy. Hoboken, NJ: John Wiley \& Sons.

CSCSNS. (2010). Population Survey. Moscow, Russia: Centre for Studies of Civil Society and the Nonprofit Sector of the National Research University Higher School of Economics.

CSGVP. (2004). Canada Survey of Giving, Volunteering, and Participating 2004. Toronto, Canada: Statistics Canada.

De Wit, A., \& Bekkers, R. H. F. P. (2013). Look who's crowding-out! 42nd ARNOVA Annual conference, 2013

De Wit, A., Neumayr, M., Handy, F., \& Wiepking, P. (2018). Do government expenditures shift private philanthropic donations to particular fields of welfare? Evidence from cross-country data. European Sociological Review, 34(1), 6-21.

Duquette, N. J. (2016). Do tax incentives affect charitable contributions? Evidence from public charities' reported revenues. Journal of Public Economics, 137, 51-69.

Einolf, C. J. (2017). Cross-national differences in charitable giving in the west and the world. Voluntas: International Journal of Voluntary and Nonprofit Organizations, 28(2), 472-491.

Elff, M., Heisig, J. P., Schaeffer, M., \& Shikano, S. (2016). No Need to Turn Bayesian in Multilevel Analysis with Few Clusters: How Frequentist Methods Provide Unbiased Estimates and Accurate Inference. 
ENAFI. (2005). Encuesta Nacional De Filantropía (ENAFI) [National Survey on Philanthropy] 2005. Project on Philanthropy and Civil Society. Mexico: ITAM.

ESS. (2002). European Social Survey, Wave I [computer file]. Bergen, Norway: Norwegian Social Science Data Services.

EU Russia Civil Society Forum. (2017). 2017 Report on the State of Civil Society in the EU and Russia. Berlin, Germany: EU Russia Civil Society Forum.

Papacostas, A. (2008). Eurobarometer 62.2: Agricultural Policy, Development Aid, Social Capital, and Information and Communication Technology, November-December 2004.

Galaskiewicz, J., \& Burt, R. S. (1991). Interorganization Contagion in Corporate Philanthropy. Administrative Science Quarterly, 88-105.

Galaskiewicz, J., \& Wasserman, S. (1989). Mimetic Processes within an Interorganizational Field: An Empirical Test. Administrative Science Quarterly, 34(3), 454-479.

Gallup. (2018). The Gallup World Poll. Washington: Gallup.

Giddens, A. (2004). The Constitution of Society: Outline of the Theory of Structuration. Cambridge, UK: Polity Press.

Giving USA. (2016). Giving USA 2016: The Annual Report on Philanthropy for the Year 2015. Indianapolis, IN: Lilly Family School of Philanthropy, IUPUI Indiana University.

Handy, F. (2000). How We Beg: The Analysis of Direct Mail Appeals. Nonprofit and Voluntary Sector Quarterly, 29(3), 439-454. 
Haski-Leventhal, D., Katz, H., \& Yogev-Keren, H. (2011). Philanthorpy in Israel 2008: Pattern of Volunteering, Giving and Organ Donations.

HBS. (2005). Household Budget Survey, 2005 [machine-readable datafile]. Dublin, Ireland: Irish Social Science Data Archive. Retrieved from www.ucd.ie/issda

Healy, K. (2006). Last Best Gifts: Altruism and the Market for Human Blood and Organs. University of Chicago Press.

Heutel, G. (2014). Crowding out and Crowding in of Private Donations and Government Grants. Public Finance Review, 42(2), 143-175.

Hogg, E. (2017). What Regulation, Who Pays? Public Attitudes to Charity Regulation in England and Wales. Nonprofit and Voluntary Sector Quarterly, 47(1), 72-88.

Hoolwerf, B., \& Schuyt, T. N. M. (2017). Giving in Europe. The State of Research on Giving in 20 European Countries. Amsterdam, the Netherlands: European Research Network on Philanthropy.

Huck, S., \& Rasul, I. (2010). Transactions costs in charitable giving: evidence from two field experiments. The BE Journal of Economic Analysis \& Policy, 10(1).

Hu, M., \& Guo, C. (2016). Fundraising policy reform and its impact on nonprofits in China: A view from the trenches. Nonprofit Policy Forum, 7(2), 213-236.

Ingram, P., \& Clay, K. (2000). The Choice-within-Constraints New Institutionalism and Implications for Sociology. Annual Review of Sociology, 26(1), 525-546. 
Japan Fundraising Association. (2010). KifuHakusho 2010 [Giving Japan 2010]. Tokyo, Japan: Nihon Keidanren Suppan.

Johnson, E. J., \& Goldstein, D. (2003). Medicine. Do Defaults Save Lives? Science (New York, NY), 302(5649), 1338-1339.

Kaminska, O., \& Lynn, P. (2017). Survey-Based Cross-Country Comparisons Where Countries Vary in Sample Design: Issues and Solutions. Journal of Official Statistics, $33(1), 123-136$.

\section{.LHYLW5\$)UDQNHQKXLV:(:DOGRUS/-\%RUVERRP'6LPSVRQIV}

Paradox in Psychological Science: A Practical Guide. Frontiers in Psychology, 4, 513.

Kingma, B. (1989). An Accurate Measurement of the Crowd-out Effect, Income Effect and Price Effect for Charitable Contributions. Journal of Political Economy, 97, 11971207.

Knowles, S., \& Servátka, M. (2015). Transaction costs, the opportunity cost of time and procrastination in charitable giving. Journal of public economics, 125, 54-63.

Low, N., Butt, S., Ellis, P., \& Davis Smith, J. (2007). Helping Out: A national survey of volunteering and charitable giving. National Centre for Social Research.

Lu, J. (2016). The Philanthropic Consequence of Government Grants to Nonprofit Organizations. Nonprofit Management and Leadership, 26(4), 381-400. 
Lyons, M., \& Passey, A. (2007). Giving Australia, Individual and Household Survey 2005 [computer file]. Canberra: Australian Social Science Data Archive, The Australian National University.

Mair, J., \& Hehenberger, L. (2014). Front-Stage and Backstage Convening: The Transition from Opposition to Mutualistic Coexistence in Organizational Philanthropy. Academy of Management Journal, 57(4), 1174-1200.

Marx, B. M. (2015). Has Regulation of Charitable Foundations Thrown the Baby out with the Bath Water? Journal of Public Economics, 129, 63-76.

Mirabella, R. M., Gemelli, G., Malcolm, M., \& Berger, G. (2007). Nonprofit and Philanthropic Studies: International Overview of the Field in Africa, Canada, Latin America, Asia, the Pacific, and Europe. Nonprofit and Voluntary Sector Quarterly, 36(4), 110S-135S.

Mirabella, R. M., \& Wish, N. B. (2001). University-Based Educational Programs in the Management of Nonprofit Organizations: An Updated Census of US Programs. Public Performance \& Management Review, 25(1), 30-41.

Mosley, J. E., \& Galaskiewicz, J. J. (2010). The role of foundations in shaping social welfare policy and services: the case of welfare reform. In American foundations: Roles and contributions (pp. 182-204). Brookings Institution Press.

1HXPD\U0+DQG】)\&KDULWDEOHJLYLQJ:KDWLQIOXHQFHVGRQRUVIFKRLFHDPRQJ different causes? Voluntas: International Journal of Voluntary and Nonprofit Organizations, 30(4), 783-799. 
Neumayr, M., \& Schober, C. (2009). Ergebnisse einer repräsentativen Bevölkerungsbefragung zum Spendenverhalten in Österreich [Findings on giving in Austria from a representative population survey].Vienna, Austria: Vienna University of Economics and Business.

North, D. C. (1990). Institutions, Institutional Change and Economic Performance. Cambridge, UK: Cambridge University Press.

North, D. C. (1992). Transaction costs, institutions, and economic performance (pp. 13-15). San Francisco, CA: ICS Press.

Oanda. (2014). Historical Currency Converter. https://www.oanda.com/fx-forbusiness/historical-rates. [Accessed Aug 1, 2018].

Pennerstorfer, A., \& Neumayr, M. (2017). Examining the Association of Welfare State Expenditure, Non-Profit Regimes and Charitable Giving. Voluntas: International Journal of Voluntary and Nonprofit Organizations, 28(2), 532-555.

Pew Research Center. (2012). Table: religious composition by country, in percentages. Pew Research Center.

Pessi, A. B., \& Grönlund, H. (2008). Auttaminen [machine-readable datafile]. Helsinki: University of Helsinki.

Philanthropy Age. (2016). Arab Giving Survey 2016. Philanthropy in the GCC. Abu Dhabi, UAE: Philanthropy Age.

Reich, R. (2006). Philanthropy and Its Uneasy Relation to Equality. Philosophy and Public Policy Quarterly, 26(3/4), 17-26.

Robinson, W. S. (2009). Ecological Correlations and the Behavior of Individuals. International Journal of Epidemiology, 38(2), 337-341. 
Rooney, P., Steinberg, K., \& Schervish, P. G. (2004). Methodology Is Destiny: The Effect of Survey Prompts on Reported Levels of Giving and Volunteering. Nonprofit and Voluntary Sector Quarterly, 33(4), 628-654.

Salamon, L. M., \& Anheier, H. K. (1992). In search of the non-profit sector. I: The question of definitions. Voluntas: International Journal of Voluntary and Nonprofit Organizations, 3(2), 125-151.

Salamon, L. M., Sokolowski, S. W., \& Haddock, M. A. (2017). Explaining Civil Society Development. A Social Origins Approach. Baltimore, MD: John Hopkins University Press.

Sargeant, A. (1999). Charitable Giving: Towards a Model of Donor Behaviour. Journal of Marketing Management, 15(4), 215-238.

Saunders-Hastings, E. (2018). Plutocratic Philanthropy. The Journal of Politics, 80(1), 149161.

Schervish, P. G., \& Havens, J. J. (1997). Social Participation and Charitable Giving: A Multivariate Analysis. Voluntas, 8(3), 235-226.

Schlegelmilch, B. B., Love, A., \& Diamantopoulos, A. (1997). Responses to Different Charity Appeals: The Impact of Donor Characteristics on the Amount of Donations. European Journal of Marketing, 31(8), 548-560.

Schupp, J. (2009). 25 Jahre Sozio-Oekonomisches Panel - Ein Infrastrukturprojekt Der Empirischen Sozial- Und Wirtschaftsforschung in Deutschland. Zeitschrift Für Soziologie, 38(5), 350-357. 
Scott, W. R. (2008). Institutions and Organizations: Ideas, Interests, and Identities. London, UK: Sage Publications.

Simpson, B., \& Willer, R. (2015). Beyond Altruism: Sociological Foundations of Cooperation and Prosocial Behavior. Annual Review of Sociology, 41, 43-63.

Sokolowski, S. W. (2013). Effects of Government Support of Nonprofit Institutions on Aggregate Private Philanthropy: Evidence from 40 Countries. Voluntas: International Journal of Voluntary and Nonprofit Organizations, 24(2), 359-381.

Stadelmann-Steffen, I., \& Freitag, M. (2011). Making Civil Society Work: Models of Democracy and Their Impact on Civic Engagement. Nonprofit and Voluntary Sector Quarterly, 40(3), 526-551.

Strauss, J., Witoelar, F., Sikoki, B., \& Wattie, A. M. (2009). The fourth wave of the Indonesian Family Life Survey (IFLS4): overview and field report. RAND Corporation.

Te Grotenhuis, M., Eisinga, R., \& Subramanian, S. V. (2011). 5RELQVRQIV(FRORJLFDO Correlations and the Behavior of Individuals: Methodological Corrections. International Journal of Epidemiology, 40(4), 1123-1125.

The Beautiful Foundation. (2006). Giving Korea 2006. Seoul, Korea: The Beautiful Foundation.

TSCS. 2009. Taiwan Social Change Survey. Questionnaire II, Phase 5, Wave 5. Taipei, Taiwan: Center for Survey Research, Academia Sinica.

Tukey, J. (1962). The Future of Data Analysis. The Annals of Mathematical Statistics, 33(1), $1-67$. 
United Nations. (2017). World population prospects: the 2017 revision. DVD Edition: https://esa. un. org/unpd/wpp/Download/Standard/Population.

U. S. Bureau of Labor Statistics. (2014). Archived Consumer Price Index Detailed Reports. https://www.bls.gov/cpi/tables/detailedreports/home.htm. [Accessed Aug 1, 2018].

Vandor, P., Traxler, N., Millner, R., \& Meyer, M. (Eds.). (2017). Civil Society in Eastern Europe: Challenges and Opportunities. Vienna, Austria: Este Stiftung.

Wagner, G. G., Frick, J. R., Schupp, J., Anger, S., Giesselmann, M., Goebel, J., ... \& Liebau, E. (2010). German Socio-oeconomic Panel Study (SOEP), data of the years 19842010. Data file Version, 27.

Wiepking, P. (2009). Giving France [machine-readable data file]. Amsterdam: VU University, Philanthropic Studies.

Wiepking, P., \& Bekkers, R. (2012). Who Gives? A Literature Review of Predictors of Charitable Giving. Part Two: Gender, Family Composition and Income. Voluntary Sector Review, 3(2): 217-245.

Wiepking, P., Bekkers, R. H. F. P., Schuyt, T. N. M., \& Gouwenberg, B. M. (2006). Giving in the Netherlands Panel Study 2005 [machine-readable data file]. Amsterdam, the Netherlands: VU University, Philanthropic Studies.

Wiepking, P. \& Handy, F. (Eds.). (2015). The Palgrave Handbook of Global Philanthropy. Hampshire, UK: Palgrave Macmillan.

Wiepking, P., \& Handy, F. (2016a). Documentation Individual International Philanthropy Database (IIPD). A Comparative Study of Global Giving. Erasmus University Rotterdam. 
Wiepking, P., \& Handy, F. (2016b). Individual International Philanthropy Database, Version 1 [machine-readable data file]. Rotterdam: Erasmus University Rotterdam.

Wiepking, P., \& Maas, I. (2009). Resources That Make You Generous: Effects of Social and Human Resources on Charitable Giving. Social Forces, 86(4), 1973-1996.

Wilhelm, M. O. (2005). The Center on Philanthropy Panel Study [machine-readable data file].

Wollebæk, D. \& Sivesind K. H. (2010). Fra Folkebevegelse Til Filantropi? Frivillig Innsats $i$ Norge 1997-2009 [From Popular Movement to Philanthropy? Volunteering in Norway 1997-2009]. Oslo, Norway: Senter for forskning på sivilsamfunn og frivillig sektor.

Wuthnow, R. (1991). Acts of Compassion: Caring for Others and Helping Ourselves. Princeton: Princeton University Press.

Yörük, B. K. (2009). How Responsive Are Charitable Donors to Requests to Give? Journal of Public Economics, 93(9), 1111-1117. 


\section{Biographical Paragraphs}

Pamala Wiepking is the Visiting Stead Family Chair in International Philanthropy and Visiting Associate Professor of Philanthropic Studies at the IU Lilly Family School of Philanthropy and Professor of Societal Significance of Charitable Lotteries at the Vrije Universiteit Amsterdam. She studies international and interdisciplinary explanations for philanthropy with the aim to help create more generous societies.

Femida Handy is a Professor of Social Policy at the School of Social Policy and Practice at the University of Pennsylvania and the Director of the PhD program. Her research and teaching focus on the economics of the nonprofit sector, volunteering, philanthropy, nonprofit management, entrepreneurship, and microfinance. 


\section{Table 1. Measurements}

\section{Dependent variables}

Incidence and level of philanthropic gifts. Across most datasets included in the IIPD, respondents have been asked whether or not they made any philanthropic donations over the period of a year, and if so, how much they donated. ${ }^{1}$ Amount donated is calculated in 2012 US Dollars. To limit the influence of outliers on our results, for each country we winsorized the level of philanthropic gifts at 99 percent, thus setting the top one percent donations to the level of the $99^{\text {th }}$ percentile donation (Tukey, 1962; De Wit et al., 2018). We analyze the natural log of amount donated in our analyses, which estimates the relationship between the measures of institutionalization and the relative change in individual amounts donated.

\section{Measures of institutionalization}

Ease of forming philanthropic organizations7KH+XGVRQ,QVWLWXWHIV,QGH[RI3KLODQWKURSLF (Adelman et al., 2015) includes a measure for the ease, and to some extend fairness, of forming, registering, operating, and dissolving philanthropic organizations. This measure is based on an opinion survey under experts representing their countries of expertise, providing a score from one to five to each of the following three items: 1) To what extent can individuals form and incorporate the organizations defined?; 2) To what extent are CSOs free to operate without excessive government interference?; 3) To what extent is there government discretion in shutting down CSOs? The average score on these three questions is used as the measure of philanthropic freedom. A higher score indicates more philanthropic freedom. Israel, Norway, Taiwan, South Korea and Switzerland were not included in the 2015 Index of Philanthropic Freedom. The scores for these countries were provided by the philanthropy country experts who participated in this project.

Fiscal incentives system. A report by the Charities Aid Foundation (CAF, 2016) surveyed lawyers across 26 countries and created seven typologies of tax incentive systems: 1) Egalitarian; 2) Egalitarian \& Pragmatic; 3) Pragmatic; 4) Pragmatic \& Transitional; 5) Transitional; 6) Transitional \& Restrictive; 7) Restrictive. The CAF did not classify the Netherlands, Norway, Finland, South Korea, Austria, Indonesia, Japan, Israel, Germany and Switzerland. We asked the country experts involved in this project to classify their country according to this typology. Egalitarian regimes are focused on creating equal fiscal incentives for all donors. This does cause these regimes to be more complex to understand and use by donors than for example pragmatic regimes. Pragmatic regimes, such as the United States and Australia, may be easier to understand, but in those regimes the benefits are not equally distributed. Typically, those with higher incomes receive higher benefits. Transitional systems are categorized as easy to understand, and allowing for future liberalization, but typically have poor incentives for ordinary donors. Restrictive regimes are typically heavily politicized, include a narrow range of causes and discourage individuals to claim tax deduction for donations (CAF, 2016).

Number of nonprofit education programs. The number of professional training venues for philanthropy professionals is based on research done by Mirabella and colleagues (Mirabella \& Wish, 2001; Mirabella et al., 2007). For the United States, they inventoried the number of graduate degree programs with at least one course in the management of nonprofit organizations (Mirabella \& Wish, 2001). In a study from 2007, they surveyed universities and colleges worldwide to locate programs in nonprofit management education. For Indonesia, which was not included in these studies, we conducted an online search in 2016 and found no evidence for nonprofit management education programs.

Type of fundraising regime. Breeze \& Scaife (2015) designed a typology of five types of fundraising regimes indicating the level of development of the fundraising profession and fundraising technology and more positive public attitudes towards fundraising among the public. Based on these characteristics, they classified the countries included in the IIPD according to this typology of fundraising regimes, where countries with the lowest levels of development on these criteria were classified as embryonic regimes, and countries with the highest level of development were classified as advanced regimes. The five types of fundraising regimes:: 1) Embryonic fund-raising regimes; 2) Emerging fund-raising regimes; 3) Evident fund-raising regimes; 4) Established fund-raising regimes; 5) Advanced fund-raising regimes.

Proportion nonprofit revenue from public sources: :HXVHWKHSURSRUWLRQRISKLODQWKURSLFRU revenue coming from public sector sources, as estimated in the John Hopkins Comparative Nonprofit Sector Project (Salamon et al., 2017, appendix B, p. 277). Across the 41 countries included in this project, governments provided on average $35.3 \%$ of the funding for philanthropic organizations in the late twentieth and early twenty-first century (Salamon et al., 2017) ${ }^{2}$. No information was available for Taiwan and Indonesia. For Taiwan the Palgrave Handbook on Global Philanthropy (Wiepking \& Handy, 2015) SURYLGHVDQHVWLPDWLRQRISHUFHQWDJHRISKLODQWKURSLFRUJDQL]DWLRQVIUHYHQ sources. For Indonesia we could not find any information about public sector support for philanthropic organizations. 
Proportion religiously affiliated. We were unable to locate a measure for the proportion of people indicating to have a religious affiliation in a country for years preceding the measures for giving in the IIPD. We were able to locate the proportion of people estimated to not belong to any religious affiliation in all countries in the IIPD for 2010 (Pew Research Center, 2012). We used (1 - the proportion religiously unaffiliated to estimate the proportion religiously affiliated). ${ }^{3}$

\section{Individual level control variables}

The analyses control for individual level measures of age in years, gender, educational level in three categories, whether or not the respondent is married, and the natural log of income.

Notes: ${ }^{1}$ In the datasets from the United Kingdom and Indonesia the reference period was four weeks and in the dataset from Ireland, the average weekly donation was included (based on a reference period of two weeks), we recalculated this to the total amount donated over the course of a year, by multiplying the amount donated with respectively 13 and 52 . Of course this also has consequences for the proportion of donors in those countries, which is likely underestimated compared to the other countries in the IIPD, which use a yearly reference period for measuring donations. The dataset from the United States only captures donations above 25 U.S. dollar; ${ }^{2}$ 7KLVPHDVXUHLVEDVHGRQWKH‡*RYHUQPHQWVKDUHRI\&6UHYHQXH·LQ6DODPRQ6RNRORZVNLDQG+DGGI (2017:279)7KHISURYLGHWKHIROORZLQJGHILQLWLRQ\$7KHUHYHQXHVRIFLYLOVRFLHWIRUJDQL]DWLRQVFR variety of sources. For the sake of convenience, we have grouped these into three categories: fees, which includes private payment for services, membership dues, and investment income; philanthropy, which includes individual giving, foundation giving and corporate giving; and government or public sector support, which includes grants, contracts, and voucher or third-party payments from all levels of government, including government financed social security systems that operate as quasi-nongovernmental organizations." (Salamon et al. 2017:274)7KHODVWFDWHJRULLVWKH†*RYHUQPHWH KHQARI:HFRXOGQRWILQGWKHH[DFW years the proportion nonprofit revenue from public sources pertain to for the various countries included in the John Hopkins Comparative Nonprofit Sector Project. Salamon, Sokolowski \& Haddock state that the data for

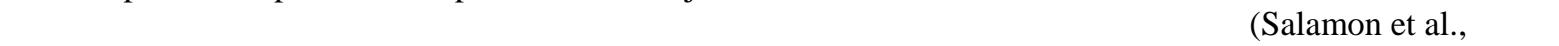
2017:274); ${ }^{3}$ Pew Research Center (2012) derived the proportion of religiously unaffiliated from the 2010 revision of the United Nations World Population Prospects Data 2010 (United Nations 2011), which we were unable to gain direct access to. We acknowledge that the proportion of religiously affiliated may differ from the proportion we estimate by using ( 1 - the proportion of religiously unaffiliated), and that there may be differences across countries in wKHWKHUVRPHRQHZKRLVLGHQWLILHGDVQRWUHOLJLRXVOIXQDIILOLDWHGIL affiliated. 


\begin{tabular}{|c|c|c|c|c|c|c|c|c|c|}
\hline Country & $\mathbf{N}$ & $\begin{array}{r}\begin{array}{r}\text { Proportion } \\
\text { donors }\end{array} \\
\end{array}$ & $\begin{array}{r}\text { Amount } \\
\text { donated }^{1}\end{array}$ & $\begin{array}{r}\text { Ease of } \\
\text { forming } \\
\text { philanthropic } \\
\text { organizations }^{\mathbf{a}} \\
\end{array}$ & $\begin{array}{r}\text { Fiscal } \\
\text { incentives } \\
\text { system }^{b} \\
\end{array}$ & $\begin{array}{r}\text { Number } \\
\text { of } \\
\text { nonprofit } \\
\text { education } \\
\text { programs } \\
\mathrm{c}\end{array}$ & $\begin{array}{r}\text { Type of } \\
\text { fund- } \\
\text { raising } \\
\text { regime }^{d} \\
\end{array}$ & $\begin{array}{r}\text { Proportion } \\
\text { nonprofit } \\
\text { revenue from } \\
\text { public } \\
\text { sources } \\
\end{array}$ & $\begin{array}{r}\text { Proportion } \\
\text { religiously } \\
\text { affiliated }^{\mathrm{f}}\end{array}$ \\
\hline Australia & 6,175 & 0.88 & 480 & 4.9 & 3 & 9 & 4 & 0.31 & 0.76 \\
\hline Austria & 816 & 0.65 & 53 & 4.4 & 3 & 1 & 3 & 0.50 & 0.87 \\
\hline France & 1,195 & 0.66 & 158 & 4.3 & 1 & 1 & 4 & 0.58 & 0.72 \\
\hline Germany & 15,194 & 0.43 & 127 & 5.0 & 3 & 5 & 4 & 0.64 & 0.75 \\
\hline Indonesia & 10,412 & 0.49 & 34 & 3.0 & 7 & 0 & 1 & $\mathrm{n} / \mathrm{a}$ & 1.00 \\
\hline Ireland & 6,884 & 0.62 & 556 & 4.7 & 1 & 2 & 3 & 0.77 & 0.94 \\
\hline Israel & 830 & 0.51 & 362 & 4.5 & 3 & 5 & 3 & 0.64 & 0.97 \\
\hline Japan & 5,072 & 0.35 & 30 & 4.7 & 1 & 8 & 3 & 0.45 & 0.43 \\
\hline South Korea & 995 & 0.78 & 183 & 3.3 & 1 & 7 & 3 & 0.24 & 0.54 \\
\hline Switzerland & 5,719 & 0.80 & 539 & 5.0 & 2 & 3 & 4 & 0.35 & 0.88 \\
\hline Taiwan & 1,869 & 0.63 & 159 & 4.7 & 3 & 1 & 2 & 0.28 & 0.87 \\
\hline United Kingdom & 1,685 & 0.95 & 989 & 4.7 & 2 & 22 & 4 & 0.47 & 0.79 \\
\hline United States & 7,251 & 0.65 & 1427 & 4.7 & 3 & 137 & 5 & 0.31 & 0.84 \\
\hline
\end{tabular}

Notes: for a description of the variables, see Table $1 ;{ }^{1}$ in 2012 US Dollar (winzorized).

Sources: IIPD (2016); ${ }^{a}+$ XGVRQ,QVWLWXWHIV,QGH[RI3KLODQWKAdRShA) UtHH,GPPP5), from no philanthropic freedom (1) to complete philanthropic freedom (5); ${ }^{\mathrm{b}}$ Charities Aid Foundation (CAF, 2016), seven systems, from egalitarian to restrictive: 1 "Egalitarian" 2 "Egalitarian \& Pragmatic" 3 "Pragmatic" 4 "Pragmatic \& Transitional" 5 "Transitional" 6 "Transitional \& Restrictive" 7 "Restrictive"; ${ }^{\text {c United }}$ States: Mirabella \& Wish (2001); all other countries (except Indonesia): Mirabella et al. (2007); ${ }^{\mathrm{d}}$ Palgrave Handbook on Global Philanthropy 
(Breeze \& Scaife, 2015), from embryonic to advanced: 1 "Embryonic fund-raising regimes" 2 "Emerging" 3 "Evident" 4 "Established" 5 "Advanced"; e John Hopkins Comparative Nonprofit Sector Project (Salamon, Sokolowski, \& Haddock, 2017) and Palgrave Handbook on Global Philanthropy (Wiepking \& Handy, 2015) (for Taiwan); ${ }^{\mathrm{f}}$ Pew Research Center (2012). 
Table 3. Descriptive statistics for the measures of institutionalization

\begin{tabular}{lrrrrrr}
\hline Variable & $\mathrm{N}_{\text {individual }}$ & $\mathrm{N}_{\text {country }}$ & Mean & Std. Dev. & Min & Max \\
\hline $\begin{array}{l}\text { Ease of forming philanthropic } \\
\text { organizations }\end{array}$ & 118,788 & 19 & 4.04 & 1.06 & 2.4 & 5 \\
$\begin{array}{l}\text { Fiscal incentives system } \\
\text { Number of nonprofit education }\end{array}$ & 118,788 & 19 & 3.49 & 2.14 & 1 & 7 \\
$\begin{array}{l}\text { programs } \\
\text { Type of fundraising regime }\end{array}$ & 111,537 & 18 & 5.95 & 6.90 & 0 & 22 \\
$\begin{array}{l}\text { Proportion nonprofit revenue } \\
\text { from public sources }\end{array}$ & 108,376 & 18 & 0.39 & 0.20 & 0.11 & 0.75 \\
$\begin{array}{l}\text { Proportion religiously } \\
\text { affiliated }\end{array}$ & 118,788 & 19 & 0.81 & 0.12 & 0.43 & 1.00 \\
\hline
\end{tabular}

Notes: ${ }^{1}$ without US, as US has 137 NP programs, outlier; ${ }^{2}$ no information available for Indonesia.

Sources: IIPD (2016); Adelman et al. (2015); Charities Aid Foundation (2016); Breeze \& Scaife (2015); Mirabella \& Wish (2001); Mirabella et al. (2007); Pew Research Center (2012); Salamon, Sokolowski, \& Haddock (2017); Wiepking \& Handy (2015). 
Table 4. Correlation between measures of institutionalization and amount donated to charitable organizations

\begin{tabular}{|c|c|c|}
\hline & $\begin{array}{r}\text { Amount donated }^{1}- \\
\text { individual level } \\
\text { measure }\end{array}$ & $\begin{array}{r}\text { Amount } \\
\text { donated }{ }^{1}- \\
\text { aggregated } \\
\text { country level } \\
\text { measure }\end{array}$ \\
\hline Ease of forming philanthropic organizations & $0.37 * * *$ & $0.82 * * *$ \\
\hline Number of nonprofit education programs ${ }^{2}$ & $0.22 * * *$ & $0.50 * * *$ \\
\hline Proportion nonprofit revenue from public sources ${ }^{3}$ & $0.19 * * *$ & $0.44 * * *$ \\
\hline Proportion religiously affiliated & -0.00 & 0.00 \\
\hline
\end{tabular}

Notes: ${ }^{1}$ natural log of the amount donated (winsorized) in 2012 US Dollars; $* * * p$

(two-tailed tests); ${ }^{2}$ without US $(\mathrm{N}=111,537) ;{ }^{3}$ without Indonesia $(\mathrm{N}=108,376)$; results

weighted by population scaling weight to represent the relative inclusion probability within each country.

Sources: IIPD (2016); Adelman et al. (2015); Charities Aid Foundation (2016); Breeze \& Scaife (2015); Mirabella \& Wish (2001); Mirabella et al. (2007); Pew Research Center (2012); Salamon, Sokolowski, \& Haddock (2017); Wiepking \& Handy (2015). 
Table 5. Fiscal incentive system and average incidence of giving and amount donated to charitable organizations

\begin{tabular}{|c|c|c|c|}
\hline Fiscal incentive system & Countries & $\begin{array}{c}\text { Average } \\
\text { proportion } \\
\text { donors }\end{array}$ & $\begin{array}{c}\text { Average } \\
\text { amount } \\
\text { donated }^{1}\end{array}$ \\
\hline 1 Egalitarian & $\begin{array}{l}\text { France, Canada, South } \\
\text { Korea, Japan, Ireland }\end{array}$ & 0.66 & 260 \\
\hline 2 Egalitarian \& Pragmatic & $\begin{array}{l}\text { United Kingdom, } \\
\text { Switzerland }\end{array}$ & 0.88 & 764 \\
\hline 3 Pragmatic & $\begin{array}{l}\text { Australia, Netherlands, } \\
\text { United States, Norway, } \\
\text { Austria, Taiwan, Israel, } \\
\text { Germany }\end{array}$ & 0.67 & 395 \\
\hline $\begin{array}{l}4 \text { Pragmatic \& } \\
\text { Transitional }\end{array}$ & Finland & 0.73 & 29 \\
\hline 5 Transitional & Mexico & 0.84 & 27 \\
\hline $\begin{array}{l}6 \text { Transitional \& } \\
\text { Restrictive }\end{array}$ & Russia & 0.40 & 12 \\
\hline 7 Restrictive & Indonesia & 0.49 & 34 \\
\hline \multicolumn{4}{|c|}{$\begin{array}{l}\text { Notes: }{ }^{1} \text { amount donated in } 2012 \text { US dollars (winsorized); results weighted by relative weight } \\
\text { to represent an equal number of cases for each country (1/(number of cases country / number } \\
\text { of total cases))/100). Not weighting the data or using the population weight drives the results } \\
\text { respectively towards the overrepresented or underrepresented countries in the IIPD. Here we } \\
\text { want to know what the average likelihood of giving is and amounts donated, based on the } \\
\text { fiscal system, and weight all countries evenly. } \\
\text { Sources: IIPD (2016); Charities Aid Foundation (2016). }\end{array}$} \\
\hline
\end{tabular}


Table 6. Type of fundraising regime and average incidence of giving and amount donated

\begin{tabular}{|c|c|c|c|}
\hline Type of fundraising regime & Countries & $\begin{array}{c}\text { Average } \\
\text { proportion } \\
\text { donors }\end{array}$ & $\begin{array}{c}\text { Average } \\
\text { amount } \\
\text { donated }^{1}\end{array}$ \\
\hline $\begin{array}{l}1 \text { Embryonic fund-raising } \\
\text { regimes }\end{array}$ & Indonesia & 0.49 & 34 \\
\hline $\begin{array}{l}2 \text { Emerging fund-raising } \\
\text { regimes }\end{array}$ & Mexico, Taiwan, Russia & 0.62 & 66 \\
\hline $\begin{array}{l}3 \text { Evident fund-raising } \\
\text { regimes }\end{array}$ & $\begin{array}{l}\text { Norway, Finland, South } \\
\text { Korea, Japan, Austria, } \\
\text { Ireland, Israel }\end{array}$ & 0.61 & 206 \\
\hline $\begin{array}{l}4 \text { Established fund-raising } \\
\text { regimes }\end{array}$ & $\begin{array}{l}\text { Australia, France, United } \\
\text { Kingdom, Netherlands, } \\
\text { Canada, Germany, } \\
\text { Switzerland }\end{array}$ & 0.79 & 428 \\
\hline $\begin{array}{l}5 \text { Advanced fund-raising } \\
\text { regime }\end{array}$ & United States & 0.65 & 1,427 \\
\hline \multicolumn{4}{|c|}{$\begin{array}{l}\text { Notes: }{ }^{1} \text { amount donated in } 2012 \text { US dollars (winsorized); results weighted by relative weight } \\
\text { to represent an equal number of cases for each country (1/(number of cases country / number } \\
\text { of total cases))/100). Not weighting the data or using the population weight drives the results } \\
\text { respectively towards the overrepresented or underrepresented countries in the IIPD. Here we } \\
\text { want to know what the average likelihood of giving is and amounts donated, based on the } \\
\text { fundraising regime, and weight all countries evenly. } \\
\text { Sources: IIPD (2016); Breeze \& Scaife (2015). }\end{array}$} \\
\hline
\end{tabular}


Table 7. Maximum likelihood multilevel mixed-effects regression analyses of the likelihood of giving to charitable organizations $\underline{\left(\mathrm{N}_{\text {individual }}=118,788 ; \mathrm{N}_{\text {country }}=19\right)}$

\begin{tabular}{|c|c|c|c|c|c|c|c|c|}
\hline & \multicolumn{2}{|c|}{$\begin{array}{l}\text { (Only individual } \\
\text { controls) }\end{array}$} & \multicolumn{2}{|c|}{ (1) } & \multicolumn{2}{|c|}{ (2) } & \multicolumn{2}{|c|}{ (3) } \\
\hline & OR & S.E. & OR & S.E. & OR & S.E. & OR & S.E. \\
\hline Intercept & $0.341 * * *$ & 0.083 & 0.357 & 0.535 & $0.429^{(+)}$ & 0.209 & $0.207 * * *$ & 0.074 \\
\hline \multicolumn{9}{|l|}{$\begin{array}{l}\text { Contextual measure of } \\
\text { institutionalization }\end{array}$} \\
\hline $\begin{array}{l}\text { Ease of forming philanthropic } \\
\text { organizations }\end{array}$ & & & 0.990 & 0.332 & & & & \\
\hline \multicolumn{9}{|l|}{ Fiscal incentives system ${ }^{1}$} \\
\hline Egalitarian & & & & & 0.531 & 0.346 & & \\
\hline Egalitarian \& Pragmatic & & & & & 2.112 & 1.780 & & \\
\hline Pragmatic & & & & & 0.714 & 0.425 & & \\
\hline $\begin{array}{l}\text { Pragmatic \& transitional, transitional, } \\
\text { transitional \& restrictive and } \\
\text { restrictive (ref.) }\end{array}$ & & & & & - & & & \\
\hline \multicolumn{9}{|l|}{ Type of fundraising regime } \\
\hline Embryonic & & & & & & & 1.678 & 1.689 \\
\hline Emerging & & & & & & & 2.002 & 1.302 \\
\hline Evident (ref.) & & & & & & & & \\
\hline Established & & & & & & & $2.743 *$ & 1.382 \\
\hline Advanced & & & & & & & 0.851 & 0.857 \\
\hline Country-level variance & $1.101 * *$ & 0.359 & $1.101 * *$ & 0.359 & $0.942 * *$ & 0.307 & $0.885 * *$ & .288 \\
\hline ICC & $0.251 * * *$ & 0.061 & $0.251 * * *$ & 0.061 & $0.223 * * *$ & 0.056 & $0.212 * * *$ & 0.054 \\
\hline loglikelihood model (df) & $-65,421$ & (8) & $-65,421$ & (9) & $-65,419$ & (11) & $-65,418$ & (12) \\
\hline AIC & 130,857 & & 130,860 & & 130,860 & & 130,861 & \\
\hline BIC & 130,935 & & 130,947 & & 130,967 & & 130,977 & \\
\hline
\end{tabular}


Table 7 - continued. Maximum likelihood multilevel mixed-effects logistic regression analyses of likelihood of giving to charitable organizations $\left(\mathrm{N}_{\text {individual }}=118,788 ; \mathrm{N}_{\text {country }}=19\right)$

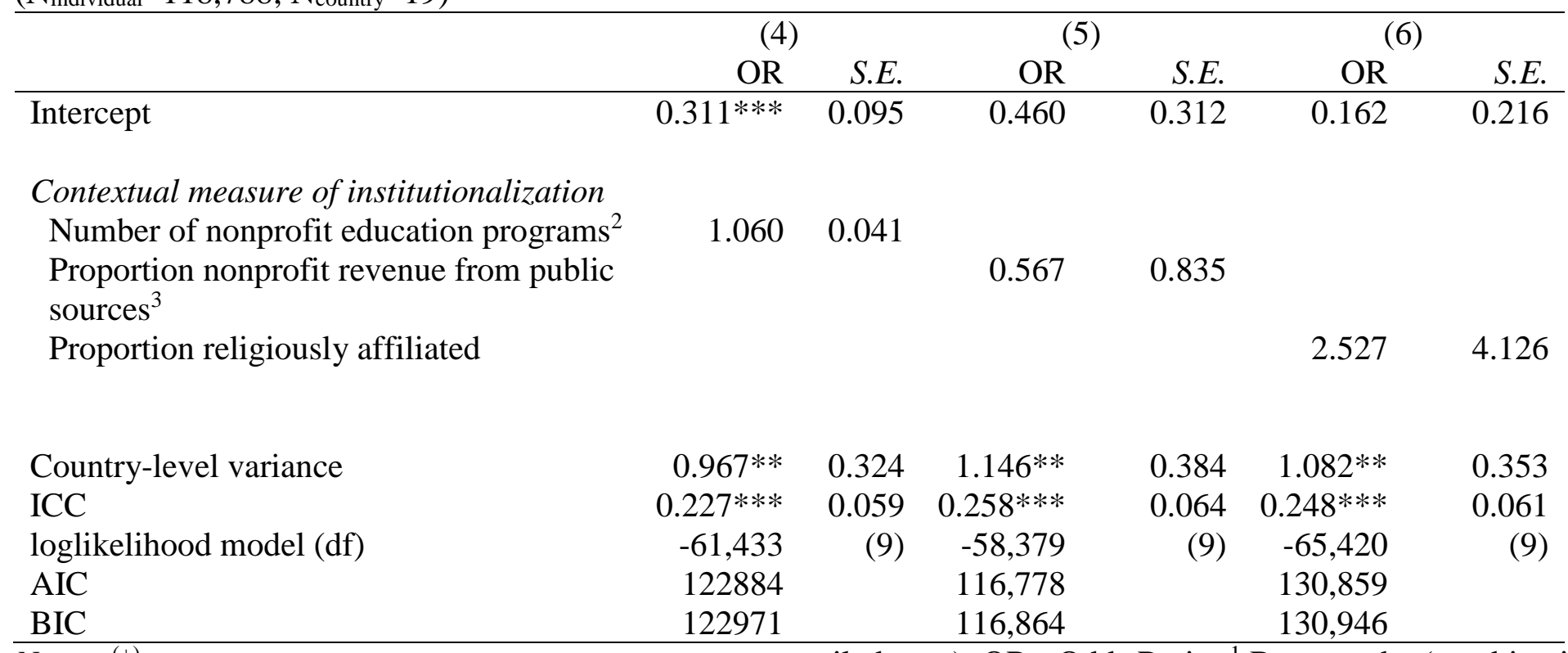

Notes: ${ }^{(+)} p \quad p \quad p \quad p \quad p$ WZR $\quad$-tailed tests); OR= Odds Ratio; ${ }^{1}$ Because the (combinations of) pragmatic, transitional
and restrictive fiscal incentive systems only relate to one country in our sample, we used these categories as reference category; ${ }^{2}$ without US $(\mathrm{N}=111,537) ;{ }^{3}$ without Indonesia $(\mathrm{N}=108,376)$; individual control variables included in the analyses (but not presented in the table): age, gender, educational level, marital status and the natural log of income.

Sources: IIPD (2016); Adelman et al. (2015); Charities Aid Foundation (2016); Breeze \& Scaife (2015); Mirabella \& Wish (2001); Mirabella et al. (2007); Pew Research Center (2012); Salamon, Sokolowski, \& Haddock (2017); Wiepking \& Handy (2015). 
Table 8. Maximum likelihood mixed-effects multilevel linear regression analyses of the natural log of the amount donated to charitable organizations $\left(\mathrm{N}_{\text {individual }}=118,788 ; \mathrm{N}_{\text {country }}=19\right)$

\begin{tabular}{|c|c|c|c|c|c|c|c|c|}
\hline & \multicolumn{2}{|c|}{$\begin{array}{l}\text { (Only individual } \\
\text { controls) }\end{array}$} & \multicolumn{2}{|c|}{ (1) } & \multicolumn{2}{|c|}{$(2)$} & \multicolumn{2}{|c|}{ (3) } \\
\hline & $\mathrm{B}$ & S.E. & $\mathrm{B}$ & S.E. & $\mathrm{B}$ & S.E. & $\mathrm{B}$ & S.E. \\
\hline Intercept & 0.074 & 0.262 & -0.819 & 1.607 & -0.335 & 0.488 & -0.471 & 0.382 \\
\hline \multicolumn{9}{|l|}{ Contextual measure of institutionalization } \\
\hline $\begin{array}{l}\text { Ease of forming philanthropic } \\
\text { organizations }\end{array}$ & & & 0.202 & 0.359 & & & & \\
\hline \multicolumn{9}{|l|}{ Fiscal incentives system ${ }^{1}$} \\
\hline Egalitarian & & & & & -0.028 & 0.654 & & \\
\hline Egalitarian \& Pragmatic & & & & & $1.954 *$ & 0.844 & & \\
\hline Pragmatic & & & & & 0.502 & 0.597 & & \\
\hline $\begin{array}{l}\text { Pragmatic \& transitional, transitional, } \\
\text { transitional \& restrictive and restrictive } \\
\text { (ref.) }\end{array}$ & & & & & - & & & \\
\hline \multicolumn{9}{|l|}{ Type of fundraising regime } \\
\hline Embryonic & & & & & & & 0.432 & 1.077 \\
\hline Emerging & & & & & & & 0.253 & 0.695 \\
\hline Evident (ref.) & & & & & & & - & \\
\hline Established & & & & & & & $1.140^{*}$ & 0.539 \\
\hline Advanced & & & & & & & 1.169 & 1.077 \\
\hline Country-level variance & $1.288 * * *$ & 0.034 & $1.266^{* * * *}$ & 0.033 & $0.947 * * *$ & 0.025 & $1.012 * * *$ & 0.027 \\
\hline Individual-level variance & $4.385 * * *$ & 0.000 & $4.385 * * *$ & 0.000 & $4.385 * * *$ & 0.000 & $4.385 * * *$ & 0.000 \\
\hline ICC & $0.227 * * *$ & 0.057 & $0.224 * * *$ & 0.056 & $0.178 * * *$ & 0.047 & $0.188 * * *$ & 0.050 \\
\hline loglikelihood model (df) & $-256,437$ & (9) & $-256,436$ & $(10)$ & $-256,434$ & (12) & $-256,434$ & (13) \\
\hline AIC & 512,891 & & 512,893 & & 512,891 & & 512,895 & \\
\hline BIC & 512,978 & & 512,990 & & 513,008 & & 513,020 & \\
\hline
\end{tabular}


Table 8 - continued. Maximum likelihood mixed-effects multilevel linear regression analyses of the natural log of the amount donated to charitable organizations $\left(\mathrm{N}_{\text {individual }}=118,788 ; \mathrm{N}_{\text {country }}=19\right)$

\begin{tabular}{|c|c|c|c|c|c|c|}
\hline & \multicolumn{2}{|c|}{$(4)$} & \multicolumn{2}{|c|}{$(5)$} & \multicolumn{2}{|c|}{ (6) } \\
\hline & $\mathrm{B}$ & S.E. & $\mathrm{B}$ & S.E. & $\mathrm{B}$ & S.E. \\
\hline Intercept & 0.011 & 0.322 & -0.290 & 0.732 & -1.885 & 1.364 \\
\hline \multicolumn{7}{|l|}{ Contextual measure of institutionalization } \\
\hline Number of nonprofit education programs ${ }^{2}$ & $0.076^{(+)}$ & 0.041 & & & & \\
\hline $\begin{array}{l}\text { Proportion nonprofit revenue from public } \\
\text { sources }^{3}\end{array}$ & & & 0.854 & 1.588 & & \\
\hline Proportion religiously affiliated & & & & & 2.653 & 1.672 \\
\hline Country-level variance & $1.090 * * *$ & 0.030 & $1.334 * * *$ & 0.037 & $1.157 * * *$ & 0.031 \\
\hline Individual-level variance & $4.088 * * *$ & 0.000 & $4.490 * * *$ & 0.000 & $4.387 * * *$ & 0.000 \\
\hline ICC & $0.210 * * *$ & 0.055 & $0.229 * * *$ & 0.059 & $0.212 * * *$ & 0.054 \\
\hline loglikelihood model (df) & $-236,834$ & (10) & $-235,239$ & (10) & $-256,435$ & (10) \\
\hline $\mathrm{AIC}$ & 473,688 & & 470,498 & & 512,891 & \\
\hline $\mathrm{BIC}$ & 473,783 & & 470,594 & & 512,988 & \\
\hline
\end{tabular}

Notes: ${ }^{(+)} p \quad p \quad p \quad p$ WZR $\quad$-tailed tests); $) ;{ }^{1}$ Because the (combinations of) pragmatic, transitional and restrictive fiscal incentive systems only relate to one country in our sample, we used these categories as reference category; ${ }^{2}$ without US (N=111,537);

${ }^{3}$ without Indonesia $(\mathrm{N}=108,376)$; individual control variables included in the analyses (but not presented in the table): age, gender, educational level, marital status and the natural log of income.

Sources: IIPD (2016); Adelman et al. (2015); Charities Aid Foundation (2016); Breeze \& Scaife (2015); Mirabella \& Wish (2001); Mirabella et al. (2007); Pew Research Center (2012); Salamon, Sokolowski, \& Haddock (2017); Wiepking \& Handy (2015). 
Table 9. Predicted probability of making a charitable donation and linear prediction of the amount donated to charitable organizations across nineteen countries estimated for the different fiscal incentive systems

\begin{tabular}{|c|c|c|c|c|c|}
\hline $\begin{array}{l}\text { Fiscal incentive } \\
\text { system }\end{array}$ & Countries & $\begin{array}{c}\text { Predicted } \\
\text { probability } \\
\text { of making a } \\
\text { charitable } \\
\text { donation } \\
\end{array}$ & S.E. & $\begin{array}{c}\text { Linear } \\
\text { prediction of } \\
\text { amount } \\
\text { donated }^{1} \\
\end{array}$ & S.E. \\
\hline 1 Egalitarian & $\begin{array}{l}\text { France, } \\
\text { Canada, South } \\
\text { Korea, Japan, } \\
\text { Ireland }\end{array}$ & $.62 * * *$ & .10 & $14.11 * * *$ & 1.52 \\
\hline $\begin{array}{l}2 \text { Egalitarian \& } \\
\text { Pragmatic }\end{array}$ & $\begin{array}{l}\text { United } \\
\text { Kingdom, } \\
\text { Switzerland }\end{array}$ & $.87 * * *$ & .07 & $102.42 * * *$ & 1.94 \\
\hline 3 Pragmatic & $\begin{array}{l}\text { Australia, } \\
\text { Netherlands, } \\
\text { United States, } \\
\text { Norway, } \\
\text { Austria, } \\
\text { Taiwan, } \\
\text { Israel, } \\
\text { Germany }\end{array}$ & $.69 * * *$ & .07 & $23.97 * * *$ & 1.39 \\
\hline $\begin{array}{l}4 \text { Pragmatic \& } \\
\text { Transitional }\end{array}$ & Finland & $.72 * * *$ & .18 & $9.03 *$ & 2.56 \\
\hline 5 Transitional & Mexico & $.92 * * *$ & .07 & $32.88 * * *$ & 2.55 \\
\hline $\begin{array}{l}6 \text { Transitional \& } \\
\text { Restrictive }\end{array}$ & Russia & $.57 * *$ & .22 & $7.64 *$ & 2.55 \\
\hline 7 Restrictive & Indonesia & $.72 * * *$ & .18 & $19.53 * * *$ & 2.55 \\
\hline $\begin{array}{l}\text { Notes: }{ }^{(+)} p \\
\text { estimations are sig } \\
\text { Table } 7 \text { and Table } \\
\text { HVWLPDWHGZ } \\
\text { at their fullsample } \\
\text { (winsorized). }\end{array}$ & $\begin{array}{l}p p \\
p \\
\text { ificantly differe } \\
3 \text { (only differenc } \\
\text { MDWHWLWLWD } \\
\text { nean; }{ }^{1} \text { Ln amou }\end{array}$ & $\begin{array}{l}p \text { WZR } \\
\text { from } 0) ; \text { Resu } \\
\text { s that all cate } \\
\text { SUDJPDWLF } \\
\text { donated calc }\end{array}$ & $\begin{array}{l}-\mathrm{tt} \\
\text { s base } \\
\text { ries of } \\
\text { VUH } \\
\text { ated to }\end{array}$ & $\begin{array}{l}\text { d tests which in } \\
\text { n estimations it } \\
\text { e fiscal incenti } \\
\text { UHQFHFDWH } \\
\text { solute } 2012 \text { Us }\end{array}$ & $\begin{array}{l}\text { e that the } \\
\text { lel } 2 \text { in } \\
\text { tem were } \\
\text { DOORWKHUFRYDULD } \\
\text { ars }\end{array}$ \\
\hline
\end{tabular}


Table 10. Predicted probability of making a charitable donation and linear prediction of the amount donated to charitable organizations across nineteen countries estimated for the different types of fundraising regimes

\begin{tabular}{|c|c|c|c|c|c|}
\hline $\begin{array}{l}\text { Type of } \\
\text { fundraising } \\
\text { regime }\end{array}$ & Countries & $\begin{array}{c}\text { Predicted } \\
\text { probability of } \\
\text { making a } \\
\text { charitable } \\
\text { donation }\end{array}$ & S.E. & $\begin{array}{c}\text { Linear } \\
\text { prediction } \\
\text { of amount } \\
\text { donated (ln } \\
\text { calculated } \\
\text { to USD) } \\
\end{array}$ & S.E. \\
\hline $\begin{array}{l}1 \text { Embryonic } \\
\text { fund-raising } \\
\text { regimes }\end{array}$ & Indonesia & $.72 * * *$ & .191 & $19.53 * *$ & 2.74 \\
\hline $\begin{array}{l}2 \text { Emerging fund- } \\
\text { raising regimes }\end{array}$ & $\begin{array}{l}\text { Mexico, Taiwan, } \\
\text { Russia }\end{array}$ & $.75 * * *$ & .102 & $16.33 * * *$ & 1.79 \\
\hline $\begin{array}{l}3 \text { Evident fund- } \\
\text { raising regimes }\end{array}$ & $\begin{array}{l}\text { Norway, Finland, } \\
\text { South Korea, } \\
\text { Japan, Austria, } \\
\text { Ireland, Israel }\end{array}$ & $.60 * *$ & .085 & $12.68 * * *$ & 1.46 \\
\hline $\begin{array}{l}4 \text { Established } \\
\text { fund-raising } \\
\text { regimes }\end{array}$ & $\begin{array}{l}\text { Australia, France, } \\
\text { United Kingdom, } \\
\text { Netherlands, } \\
\text { Canada, Germany, } \\
\text { Switzerland }\end{array}$ & $.81 * * *$ & .056 & $39.65 * * *$ & 1.46 \\
\hline $\begin{array}{l}5 \text { Advanced fund- } \\
\text { raising regime }\end{array}$ & United States & $.56^{*}$ & .232 & $40.82 * *$ & 2.73 \\
\hline $\begin{array}{l}\text { Notes: }{ }^{(+)} p \\
\text { estimations are sign } \\
\text { Table } 7 \text { and Table } 8 \\
\text { calculated to absolu } \\
\text { Sources: IIPD }(2016\end{array}$ & $\begin{array}{l}p \\
\text { cantly different fro } \\
\text { ll other covariates } \\
2012 \text { US dollars } \\
\text { Breeze \& Scaife }\end{array}$ & $\begin{array}{l}p \text { WZR -ta } \\
0) \text {; Results basec } \\
\text { ed at their fullsa } \\
\text { sorized). } \\
\text { 15). }\end{array}$ & $\begin{array}{l}\text { lests } \\
\text { estir } \\
\text { le me }\end{array}$ & $\begin{array}{l}\text { lich indicate } t \\
\text { lons in Model } \\
{ }^{1} \mathrm{Ln} \text { amount }\end{array}$ & $\begin{array}{l}\text { the } \\
\text { in } \\
\text { onated }\end{array}$ \\
\hline
\end{tabular}


Figure 1. Average annual philanthropic donation in 2012 US Dollars per person in nineteen countries (Source: IIPD, 2016)

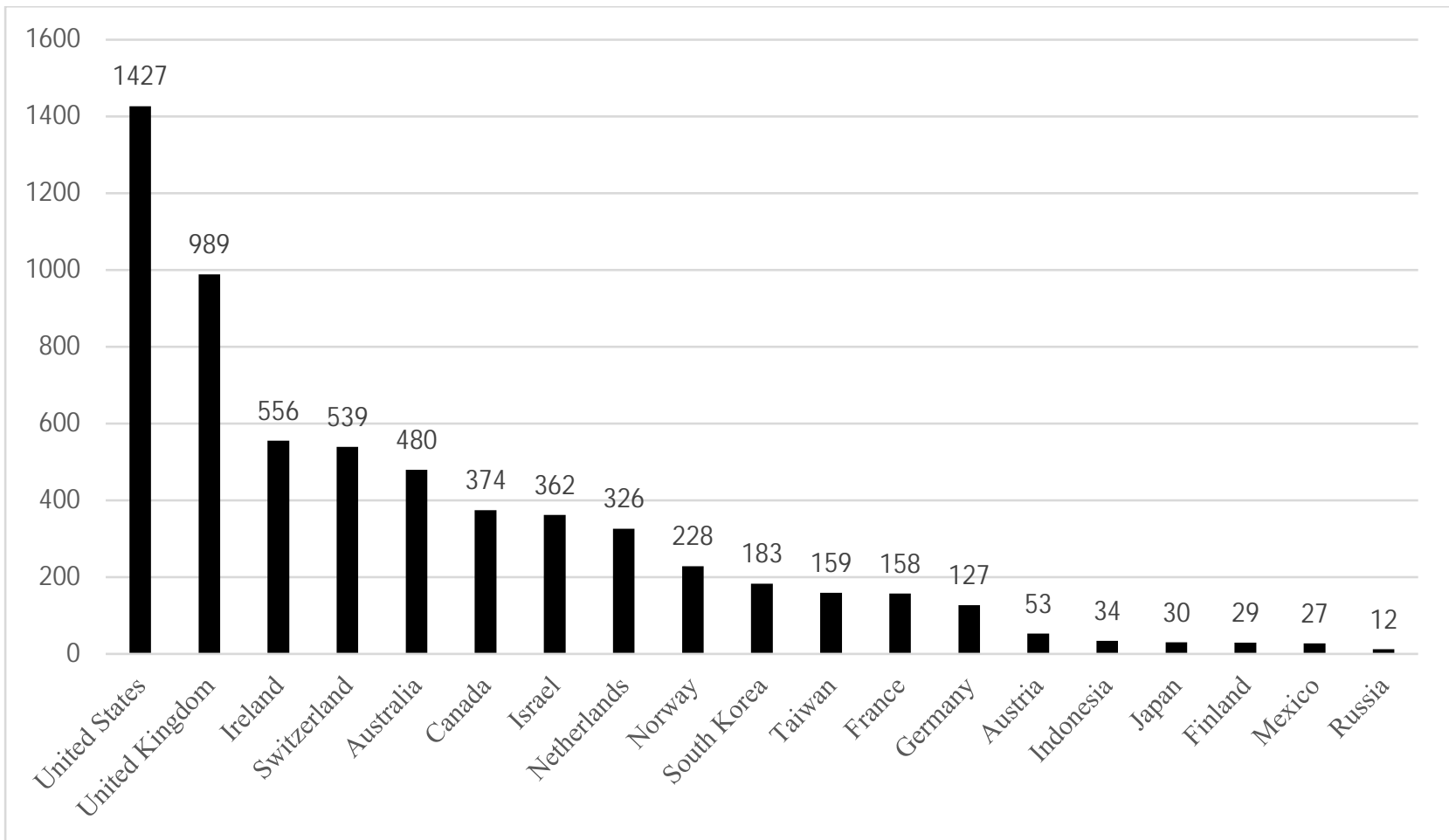

Note: The philanthropic donations per person have been measured in the local currency of each country, and have been converted to the value of 2012 U.S. dollars using historical exchange rates (Oanda 2014) and the Consumer Price Index (CPI-U) (U. S. Bureau of Labor Statistics 2014). More information can be found in Online Appendix A and the IIPD documentation (Wiepking \& Handy, 2016). 
Figure 2. Predicted probability of giving to charitable organizations for the different continuous measures of institutionalization (Adjusted Predictions with 95\% Cis; all other variables at mean)
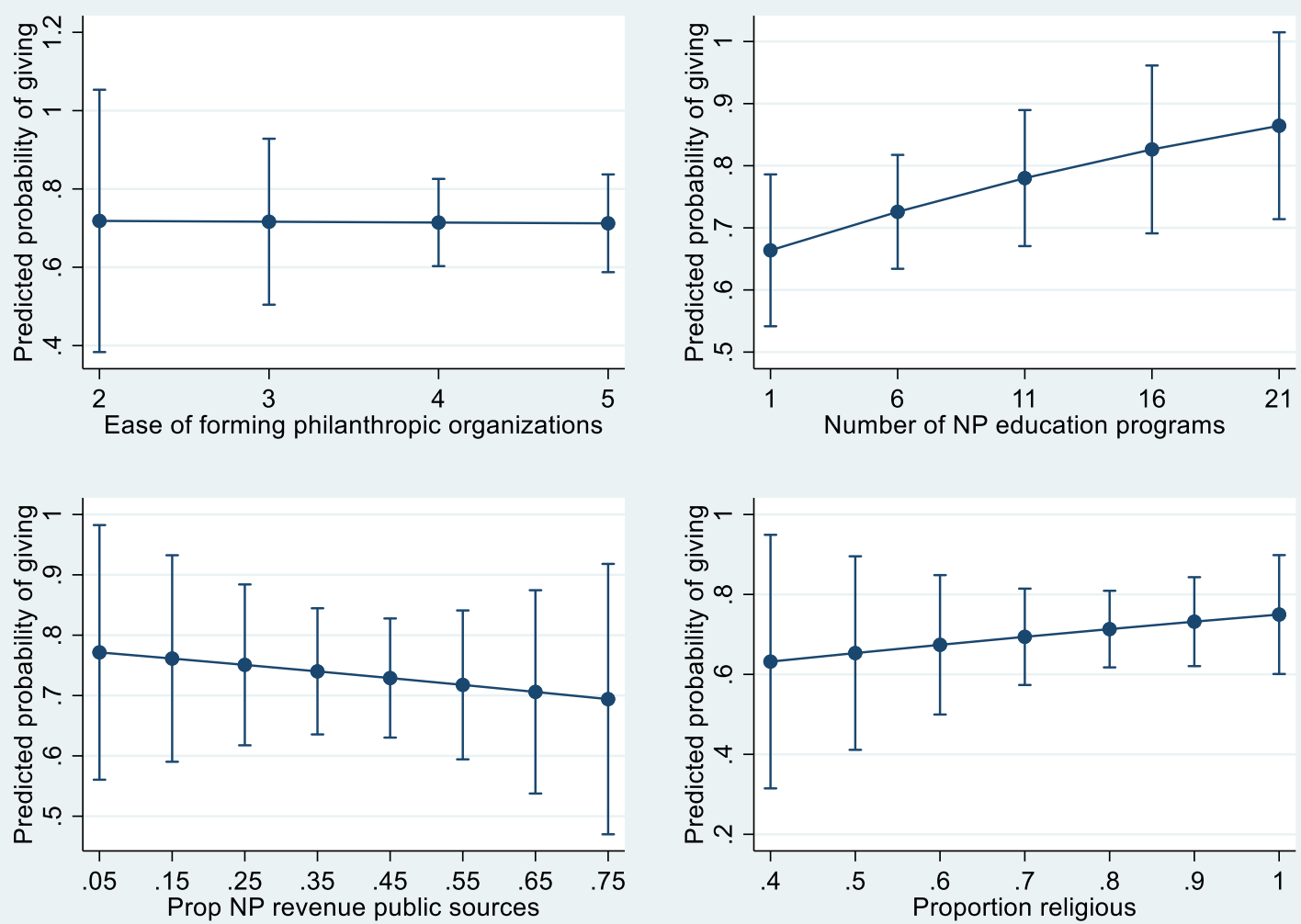

Note: Based on results in Table 7. 

















